\title{
Non-Hydropower Renewable Energy in Central Asia: Assessment of Deployment Status and Analysis of Underlying Factors
}

\author{
Elena Shadrina \\ School of International Liberal Studies, Waseda University, Nishi Waseda 1-6-1, Shinjuku-ku, \\ Tokyo 169-8050, Japan; shadrina@waseda.jp
}

Received: 12 May 2020; Accepted: 2 June 2020; Published: 9 June 2020

\begin{abstract}
Despite globally progressing energy transition, the deployment of non-hydropower renewable energy (NHRE) in Central Asia is moderate and varies by country. This paper aims to explain why Central Asian countries with significant challenges in the energy sector are least engaged in NHRE development. In doing so, the paper first reviews scholarly work on renewable energy (RE) deployment in developing countries. For assessing the NHRE development status in Central Asian countries, the paper adopts a two-stage analytical framework. First, it assesses the current situation in these states' energy sectors in connection to their economic growth and development, environmental sustainability and energy security. Then, it analyses the preparedness of the national energy sectors for NHRE diffusion in six dimensions: structure of energy sector, RE regulation, institutions and governance, capital and investment, infrastructure and business environment, and human capital. Based on the results of the two-stage analysis, the paper argues that more advanced economically and institutionally countries are more likely to commence NHRE development.
\end{abstract}

Keywords: Central Asia; non-hydropower renewable energy; renewable energy policy

\section{Introduction}

The term "renewable energy" (renewables), according to the International Renewable Energy Agency (IRENA), embraces hydro- and geothermal power, bioenergy, as well as ocean, solar, and wind energy (while small-scale hydropower (SSHP) is considered to be aligned with the concept of renewable energy, the inclusion of large-scale hydropower (LSHPP) in the category of renewables is debated). Historically, the nations were predominantly harnessing hydropower potential, for it was comparatively inexpensive and abundant [1]. Such virtues of hydropower have been especially significant for developing economies, including those in Central Asia, helping them to solve the problems of energy shortage, poverty, and inequality [2-4]. Partially because hydropower revealed some features inconsistent with sustainability [1], the improvement of commercial viability of non-hydropower renewable energy (NHRE) sources [5-7] has transformed the latter in a feasible alternative to hydropower [8]. The deployment of NHRE is uneven [9], with developed economies leading in the sector. The rationales behind the nations' renewables strategies naturally vary. Even fossil-fuel rich nations are increasingly motivated to develop renewables as one of the ways to enhance their innovative capabilities and sustainability [10,11]. Although energy-resource poor developing economies are less competent of employing renewables for the lack of domestic innovative and financing potential, they gradually incorporate NHRE solutions [12,13] helping them progress towards the attainment of the Sustainable Development Goals (SDG) [14,15].

This paper examines the case of NHRE diffusion in Central Asian countries. Kazakhstan, the most prosperous economy (categorized internationally as an upper-middle-income country), relies heavily 
on hydrocarbon resources and commodities markets. Kyrgyzstan is a lower-middle-income country, the second poorest after Tajikistan and the least urbanized economy in the region. Remittances account for $33.2 \%$ of Kyrgyzstan's GDP. Tajikistan is a low-income economy with a predominantly rural population (the urbanization rate is $27 \%$ ). Over $45 \%$ of Tajikistan's population is under the age of 20 . The lack of domestic employment opportunities results in massive labor emigration and subsequent remittances dependency equal to about one-third of GDP. Like Kyrgyzstan, Tajikistan is vulnerable to the effects of climate change, due to rapidly melting glaciers. Turkmenistan is an upper-middle-income country with the second-highest GDP per capita in Central Asia. More than 90\% of Turkmenistan's export is made up by mineral products (primarily gas), and over $90 \%$ of exports are China-oriented. Uzbekistan is a lower-middle-income economy and the most populous country in Central Asia. Uzbekistan is also vulnerable to climate change effects, as the rising average temperatures accelerate the problem of water deficit [16].

The existing literature on renewables (RE) deployment in Central Asia either concentrates on one country [17-21] or addresses RE indirectly, examining the nexus linkages [22-26]. Moreover, the geographic focus and issue coverage in Central Asian RE research is uneven. Overall, Kazakhstan is studied more comprehensively, with a greater variety of RE sources examined [27-29]. RE research on Tajikistan [30-33] and Kyrgyzstan [34,35] are mainly linked to large-scale hydropower plants (LSHPP) and water-energy nexus. While Uzbekistan's risen economic openness and newly endorsed orientation at RE deployment motivate growing scholarly interest to the country [36], studies devoted to Turkmenistan remain scarce [37]. In 2019, several brief data summaries on RE in Central Asian countries were published; they are compiled upon the publicly open sources and presented in a purely technical format [38-41].

This study bridges the existing gaps in scholarly work on RE development in Central Asia in several respects. First, it undertakes a comprehensive overview of the NHRE advancement in each Central Asian economy. Second, it examines the development of NHRE in Central Asian countries upon a two-stage analytical framework: analysis of national energy systems' efficiency; and analysis of national energy systems' readiness for RE diffusion. Third, the study incorporates a diverse range of sources. Besides internationally published data and scholarly work, this study draws upon policy documents, national and local media, as well as knowledge gained from personal communications with the respective countries' policymakers, regulators and experts during the workshops on renewable energy development in Central Asian economies organised by the ADB and CAREC Institute in 2018 in Baku and in 2019 in Almaty.

Building upon the existing research on the determinants of RE development, this study critically analyzes the case of NHRE deployment in Central Asia. This paper examines the hypothesis that more advanced economically and institutionally Central Asian countries demonstrate greater engagement in NHRE deployment. The rest of the paper is organized into five sections. The following section overviews RE research, with a particular focus on studies examining the factors behind NHRE deployment in developing economies. It also organizes relevant concepts, presents the methodological framework and describes data sources. Section 3 characterizes the performance of Central Asian national energy systems. Section 4 analyses factors determining the deployment of NHRE in Central Asian economies. Section 5 discusses principal findings and draws policy recommendations. Section 6 summarizes the arguments.

\section{NHRE Deployment in Developing Countries: Empirical Evidence, Methodology and Data}

\subsection{Literature Review}

To frame our analysis of the determinants facilitating and impeding NHRE deployment in Central Asia, we first present a succinct review of the existing research on developing countries. Bourcet [12] notes that there are differences between the factors affecting the deployment of RE in developed and developing economies and summarizes that majority of studies prove positive effect of the population 
size, RE policies, and participation in the Kyoto Protocol. In turn, the negative impact on RE diffusion is observed for traditional energy industries lobby. Income level, $\mathrm{CO}_{2}$ emissions, energy security, financial sector development and institutional quality are found to have an ambiguous influence. Studying the determinants of NHRE diversification in 117 developing countries over the period 1980-2011, Seriño [13] shows that higher levels of per capita income, technological innovation, human capital, dependence on imported energy, and crude oil price, as well as the implementation of RE policies, promote diversification. Examining 108 developing countries between 1980 and 2010, Pohl and Mulder [42] find that NHRE diffusion accelerates with the implementation of economic and regulatory instruments, higher per capita income and better schooling levels, as well as with stable democratic regimes. Increasing trade intensity, higher levels of foreign direct investment (FDI) and official development assistance (ODA), institutional and strategic policy support programs, and rapid growth in electricity consumption delay the diffusion of NHRE. Seriño [13] and Pohl and Muilder [42] agree that the abundance of hydropower and availability of fossil-fuel resources impede diversification. Pohl and Muilder [42] identify no evidence for any influence of the level of the financial sector development and weak evidence of a positive influence of the Kyoto Protocol on NHRE diffusion. Confirming findings for the financial sector, Seriño [13] claims robust evidence of the Kyoto Protocol positive influence on NHRE diversification.

Regarding economic openness, Amri [43] reports the bidirectional link between RE development and economic openness, which is critical for technology transfer and diffusion. This aspect is relevant to Kazakhstan and Kyrgyzstan, the members of the Eurasian Economic Union (together with Armenia, Belarus and Russia). Kazakhstan has been benefiting from the Eurasian Development Bank (EDB) financing and Russia's investments in RE projects [44,45]. Importantly, Yao et al. [46] finds that compared to developed economies, the developing countries reach the turning point on the U-shaped renewable energy Kuznets curve at a lower income level. Seriño [13] also demonstrates the diversification of NHRE as developing countries grow more affluent. This may be linked to the effects of technology transfer and learning-by-doing, but also to gradual reforms in still heavily subsidized or even free of charge electricity (as used to be in Turkmenistan through the year 2019) domestic electricity sectors. Bahrami et al. [37], for instance, argue that in Turkmenistan, the LCOE for wind ( 0.0435 to $0.0893 \mathrm{USD} / \mathrm{kWh}$ ) opens up large exporting opportunities. For low and lower-middle-income economies, NHRE is often seen as a plausible solution for energy cut-offs and blackouts, especially in rural areas. Eshchanov et al. [18] (p. 796) assess that, in Uzbekistan, "any need for renewable energy sources at the present time exists mainly due to the cut-offs or shortages in the traditional energy supply".

NHRE deployment in developing economies with modest own means may create greater risks of new kinds of dependencies on critical materials, foreign technology, and financial resources [47-50]. Greater deployment of RE may also intensify the risks of political dependency on a key donor of financial or technological resources, or the risks of geopolitical conflicts stirred by the complexity of resource-sharing [51,52].

Studying the impacts of renewables-related development aid, Marquardt [53] distinguishes between the effects of negative fragmentation for the local-scale projects and positive pluralism for the national level projects. Marquardt et al. [54] observe that while ODA provides expertise and financial capacity for the enhancement of energy transitions in developing countries, the aid is often loosely linked to the recipients' goals and challenges for renewables. Marquardt [55] claims that ODA cannot force energy transition, but can become a driving force for creating niches for technological experiments and policy innovations. Scaling up the niche level developments into full-fledged energy transitions is more successful when the donor considers the recipient's domestic policy priorities and complex interlinkages within macro-societal structures [56,57]. Yet, Kim [58,59] holds that donors' energy aid-giving patterns changed after the adoption of the Kyoto Protocol, and now their aid decisions are influenced by the recipient energy needs aligned with the SDG. Delina [59], Buntaine and Pizer [60] and Kim [58] argue that by trying to meet the donors' financing priorities that favor sustainable energy 
(the Norwegian Sovereign Wealth Fund, Saudi Arabia's Public Investment Fund, European Investment Bank, among others), the developing nations update their climate policies to become eligible for the ODA.

Examining NHRE development in energy-rich Kazakhstan, Turkmenistan and Uzbekistan, the NHRE deployment dilemma for the fossil-fuel-rich (FFR) developing economies is multidimensional. That is, Boute and Zhikharev [61] argue that incumbent energy companies acquire powers of vested interests in solar PV manufacturing sector and accelerate RE diffusion in Russia. This study draws relevant lessons for hydrocarbons-rich Kazakhstan. Aligning with Moe [62], arguments drawn for other cases, Boute and Zhikharev [61] (p. 1), believe that "(t)he manufacturing of clean energy equipment rather than the decarbonization of the energy system, drives Russia's renewable energy policy". This assessment is supported by the findings that the development of NHRE is associated with larger innovation intensity in the energy sector and economy at large $[11,13,63]$. Explaining the rationale behind, Mäkitie et al. [2] think that the turbulences at the commodities markets drive the reorientation of the incumbent national fossil fuel industries towards locking out the lower carbon alternatives.

The diffusion of renewable energy proliferates in economies with adequate technological, socio-economic, and political institutions. The most critical for energy transitions institutional traits involve a decent degree of flexibility and adaptability [64-66]. The problem in energy rent dependent countries is that their governments are reluctant to initiate transformations because of the associated risks of destabilization of the incumbent authority and propagation of political and socio-economic turbulences $[48,67]$. In authoritarian rent dependent economies, the political elites construct fiscal systems upon a heavy reliance on the taxation of resources. This creates an image of a state being paternalistic vis-à-vis its citizens (ample examples of this kind are the rationed per capita or per household quantities of free of charge electricity, gas, and gasoline). In reality, however, such a system fosters rampant clientelist traditions and hinders governments' accountability $[10,68]$. It is for the virtues of interdisciplinary frameworks instrumental for the analysis of complex phenomena of NHRE diffusion that the concepts of institutional theory [69,70], political economy [71] and varieties of capitalism $[26,72,73]$ are increasingly appreciated. The RE development can be enhanced by the efficient institutions and, in turn, the sector can become a driver for a range of positive shifts in the national energy sector and the economy at large. On the contrary, the RE sector may be affected by the poor practices becoming yet another channel for syphoning off the national wealth [74,75]. Putting this in perspective, developing nations who lack their own financial capacities, tend to rely on FDI and ODA when deploying RE innovations. The effectiveness of external financing is influenced by the quality of national institutions [76].

To recapitulate, developing economies with higher income level, more diversified energy mix, better educational attainment, greater economic openness, higher quality institutions, more substantial dependency on imported energy, as well as with the endorsed essential domestic RE policies and the manifested commitment to the Kyoto Protocol, are more likely to engage in NHRE deployment. Concurrently, economies with a considerable dependency on hydropower, expanding economy and rapidly rising energy demanding a profound reliance on ODA and FDI are less motivated to develop NHRE. However, and this is important for our further analysis, the review has elucidated that the effects of some determinants are ambiguous or changing over time. For instance, as a result of donors' changed sustainability priorities, the impacts of ODA and FDI seem to be switching to positive ones; or, the factor of vested interest in some post-Soviet and developing hydrocarbon-rich countries is conducive to NHRE diffusion.

Putting these observations in perspective, a variety of determinants turns Kazakhstan into the fittest candidate for the NHRE development. A number of factors seem to be favoring NHRE deployment in Uzbekistan and Turkmenistan. While Kyrgyzstan and Tajikistan seem to be less equipped to engage in RE diversification, their prospects for doing so are improving. In the following section, we outline the framework, upon which we check our hypothesis that more developed economically and institutionally countries in the region are more successful in NHRE deployment. 


\subsection{Methodological Framework and Data}

To assess the Central Asian economies' NHRE deployment status, we apply the two-stage analytical framework, which incorporates insights from the reviewed existing research and builds upon the adopted practices [77]. First, we evaluate the ability of national energy systems to meet the needs of respective Central Asian economies across three interacting dimensions: economy, security, and sustainability (Table 1). At the second stage, we assess the countries' preparedness to embrace NHRE. In doing so we examine the structure of the incumbent energy systems, and analyze the adequacy of the existing RE policies, intuitions, investments, infrastructure and human capital.

Table 1. Analytical Framework Energy System's Performance-Deployment Readiness (Source: author, adapted from [77] (p. 31); [78]; [79] (pp. 185-187)).

\begin{tabular}{|c|c|c|}
\hline Characteristics & Dimensions & Key Indicators \\
\hline \multirow[t]{3}{*}{ Energy system performance } & Economy & $\begin{array}{l}\text { Economic growth, \% } \\
\text { Population growth, \% } \\
\text { Electrification rate, \% of population } \\
\text { Energy rent, \% to GDP } \\
\text { Energy subsidies, \% to GDP } \\
\text { Net fuel exports, \% of TPES }\end{array}$ \\
\hline & Energy Security & $\begin{array}{l}\text { Net energy imports, \% of TPES } \\
\text { Diversity of energy exports/imports } \\
\text { Quality of electricity supply }\end{array}$ \\
\hline & Environmental Sustainability & $\begin{array}{l}\text { Energy intensity } \\
\mathrm{CO}_{2} \text { intensity }\end{array}$ \\
\hline \multirow{6}{*}{ NHRE deployment readiness } & Energy System Structure & $\begin{array}{l}\text { Energy supply per capita } \\
\text { Electricity system flexibility, shares of } \\
\text { hydro, gas and oil } \\
\text { Share of electricity from coal } \\
\text { Share of electricity from NHRE } \\
\text { Share of global fossil fuels reserves, \% }\end{array}$ \\
\hline & $\begin{array}{l}\text { Regulation and Political } \\
\text { Commitment }\end{array}$ & $\begin{array}{l}\text { State goals } \\
\text { Factors affecting state goals } \\
\text { (dependencies on external factors) } \\
\text { NDC commitment } \\
\text { RE policy stability } \\
\text { Energy efficiency regulations } \\
\text { RE regulations } \\
\text { Energy access regulations }\end{array}$ \\
\hline & Institutions and Governance & $\begin{array}{l}\text { State capacity and stability } \\
\text { Special interests } \\
\text { Corruption } \\
\text { Rule of law } \\
\text { Credit rating }\end{array}$ \\
\hline & Capital and Investment & $\begin{array}{l}\text { Investment freedom } \\
\text { Access to credit } \\
\text { New NHRE capacity built, \% of change }\end{array}$ \\
\hline & $\begin{array}{l}\text { Infrastructure and Business } \\
\text { Environment }\end{array}$ & $\begin{array}{l}\text { Infrastructure for extraction, } \\
\text { transportation, conversion and use } \\
\text { Technology availability } \\
\text { Logistics performance } \\
\text { Innovative business environment } \\
\text { Internet users, \% of population } \\
\text { Mobile telephone, units per } 100 \text { people }\end{array}$ \\
\hline & Human Capital & Education quality \\
\hline
\end{tabular}

For the quantitative assessments, we employ a vast range of data sources (Appendix A). The country-level analysis additionally incorporates relevant data published by the national ministries of 
energy (or respective agencies in charge of RE regulation) and national statistical services. State-owned energy companies' information helps comprehend the hierarchy of the national energy sectors and the structure of domestic electricity markets. Out of the five countries covered by this study, Turkmenistan has the sparsest data.

Similarly, the qualitative analysis draws upon a variety of accounts. A critical review of program documents (concepts and strategies), explaining the nations' long-term visions of the RE roles and outlining principal directions of the governmental policies, helps identify numerical parameters of energy transitions and enables cross-country comparisons. Examination of the regulatory aspects of RE development, such as tariff policy, pricing, taxation, foreign trade, and investment-related provisions, substantiates the analysis.

\section{Analysis of Energy System Performance}

\subsection{Energy System and Economy}

Kazakhstan and Turkmenistan are the wealthiest economies in Central Asia (Table 2). The least developed in the region, Kyrgyzstan and Tajikistan have lost precious resources and time to the revolutions of 2005 and 2010, and to the civil war of 1992-1997 and the insurgency of 2010-2015, respectively. These two could not catch up with the market transitions. Unlike the peers in the region, Uzbekistan had not experienced deep economic declines throughout its independency. However, due to its large and continuing-to-grow population, the country still has comparatively low per capita income.

Table 2. Central Asian Economies' Profiles (Source: author, based on World Bank data).

\begin{tabular}{cccccc}
\hline Indicators & Kazakhstan & Kyrgyzstan & Tajikistan & Turkmenistan & Uzbekistan \\
\hline Population, 2019, mn & 18.3 & 6.32 & 9.1 & 5.9 & 32.5 \\
\hline $\begin{array}{c}\text { Population growth, 1992-2018, } \\
\text { an. avg., \% }\end{array}$ & 0.39 & 1.29 & 1.93 & 1.61 & 1.68 \\
\hline $\begin{array}{c}\text { GDP growth, 1992-2018, an. } \\
\text { avg., \% }\end{array}$ & 3.47 & 1.93 & 2.28 & 5.04 & 4.49 \\
\hline $\begin{array}{c}\text { GDP per capita growth, } \\
\text { 1992-2018, an. avg., \% }\end{array}$ & 3.04 & 0.60 & 0.31 & 3.39 & 2.76 \\
\hline $\begin{array}{c}\text { GDP per capita, PPP (constant } \\
\text { 2011 international \$), 2018 }\end{array}$ & 24,738 & 3447 & 3061 & 17,129 & 6240 \\
\hline
\end{tabular}

Note: the latest available data for Turkmenistan are as of 2014.

Central Asian countries continue subsidizing energy. Measured as a percentage to GDP, the subsidies were the highest in Kyrgyzstan (26.4\%), followed by Uzbekistan (26.3), Turkmenistan (23), Kazakhstan (11) and Tajikistan (7.1\%) [80]. This makes conventional energy sources difficult to compete with. In 2017, the costs of NHRE in Kazakhstan were four- to five-fold higher than that of traditional. That is, the average cost of one $\mathrm{kWh}$ generated at a coal-fired facility was 7-8 tenge (US\$ 0.02), while a $\mathrm{kWh}$ generated at a wind farm cost 22 tenge (US\$ 0.07), and even more at a solar photovoltaic-34 tenge (US\$ 0.1) [81]. In Kazakhstan, the return on investment in solar PV energy is 20 to 25 years, which is unacceptable to investors [82]. Low energy tariffs undermine the competitiveness of NHRE and discourage investment in new technologies.

The effects of energy exports on the domestic economies are presented in Table 3. Since the early 2000s, oil output and exports (primarily to Europe) have been growing rapidly in Kazakhstan. Turkmenistan's gas production and exports started to increase after the commencement of gas pipeline to China in 2009. In both countries, the energy-GDP growth has been weaker and less stable than that of non-oil GDP. The contribution of oil revenues to Kazakhstan's budget has become less significant (comparison of the fiscal and external breakeven price supports such idea); correspondingly, the non-oil revenues have been increasing. In Turkmenistan, gas revenues continue to play a considerable role. 
Table 3. Selected Parameters of Fossil-Fuel-Dependent Economies (Source: retrieved from http://data.imf.org/?sk=4CC54C86-F659-4B16-ABF5-FAB77D52D2E6\&sId=1390030109571).

\begin{tabular}{cccccccc}
\hline \multirow{2}{*}{ Indicators } & \multirow{2}{*}{ Country } & \multicolumn{3}{c}{ Average } & \multicolumn{3}{c}{ Projections } \\
\cline { 3 - 7 } & & $\mathbf{2 0 0 0 - 2 0 1 5}$ & $\mathbf{2 0 1 6}$ & $\mathbf{2 0 1 7}$ & $\mathbf{2 0 1 8}$ & $\mathbf{2 0 1 9}$ & $\mathbf{2 0 2 0}$ \\
\hline \multirow{2}{*}{ Oil GDP Growth, \% } & Kazakhstan & 6.6 & -2.9 & 8.7 & 8.4 & -1.4 & 1.1 \\
& Turkmenistan & 9.0 & -4.8 & 1.7 & 5.4 & 6.6 & 4.1 \\
\hline \multirow{2}{*}{ Non-Oil GDP Growth, \% } & Kazakhstan & 7.6 & 2.4 & 2.7 & 2.7 & 5.6 & 4.8 \\
& Turkmenistan & 10.7 & 8.5 & 7.3 & 6.3 & 6.3 & 6.4 \\
\hline Crude Oil Exports, mb/d & Kazakhstan & 1.16 & 1.28 & 1.41 & 1.52 & 1.48 & 1.49 \\
\hline \multirow{2}{*}{ Natural Gas Exports, 1000 cm/d } & Turkmenistan & 0.60 & 0.65 & 0.66 & 0.64 & 0.72 & 0.76 \\
\hline \multirow{2}{*}{ Fiscal Breakeven Oil Price * } & Kazakhstan & 76.64 & 113.51 & 105.21 & 37.89 & 57.83 & 57.84 \\
& Turkmenistan & 69.10 & 45.95 & 55.94 & 63.93 & 58.91 & 57.62 \\
\hline \multirow{2}{*}{ External Breakeven Oil Price ** } & Kazakhstan & 85.93 & 86.71 & 82.67 & 81.53 & 81.50 & 77.07 \\
& Turkmenistan & 80.82 & 58.07 & 53.96 & 28.68 & 48.46 & 47.25 \\
\hline
\end{tabular}

Notes: * the oil price at which the fiscal balance is zero; ${ }^{* *}$ the oil price at which the current account balance is zero; $\mathrm{mb} / \mathrm{d}-$ million barrels a day; $\mathrm{cm} / \mathrm{d} —$ cubic meters a day.

\subsection{Energy Security}

The Soviet era-built formats of regional energy cooperation in Central Asia have been largely terminated [83]. A result of disrupted regional frameworks, poor in fossil fuels and rich in hydropower resources Kyrgyzstan and Tajikistan, became vulnerable to energy deficits, especially in winter. Tajikistan and Kyrgyzstan, who generate, respectively, $98 \%$ and $85 \%$ of electricity at large-scale hydropower plants (LSHPP), are net-importers of energy ( $30 \%$ and $50 \%$ of their energy use, respectively). The other nations in the region face the challenges of water availability, as the dependence on transboundary water ranges from critical for Turkmenistan (94\%) and Uzbekistan (77\%), to high for Kazakhstan (42\%) [84].

Kyrgyzstan and Tajikistan are increasingly challenged to match their growing demand for electricity with the existing generating capacities. Kyrgyzstan's hydropower resources are being exploited at $13 \%$ of potential [41], yet power deficit, according to local sources, reaches $25 \%$ in winter. One of the peculiar features of Kyrgyzstani HPPs is a high ratio of their wearout, for the major generating capacities were built in the 1960s and 1970s, including the largest Toktogul HPP; the majority of small-scale HPPs were constructed in the 1940-1960s. Tajikistan is ranked the top in Central Asia and the 8th in the world for its hydropower resources, with only about $5 \%$ of hydro stock being harnessed [41]. Yet, in 2009, Tajikistan had a severe energy crisis (exacerbated by the discontinuation of the Central Asian Power System format). About $60 \%$ of Tajikistan's HPPs require urgent renovation.

Ageing power generation, transmission and distribution infrastructure affects the quality of electricity supply in Central Asian economies. Electricity transmission losses, blackouts and low-quality services are affecting the nations' economic prospects. The World Bank assesses electricity losses to output in Kyrgyzstan at 24\%, Tajikistan-17, Turkmenistan-12, Uzbekistan-9 and Kazakhstan at $7 \%$. The number of power outages in a typical month for Tajikistan is 6.1 occasions of blackouts and for Uzbekistan 5.7 outages. Access to electricity in the rural areas, according to the World Bank's SE4ALL, in Kyrgyzstan is $99.7 \%$, in Tajikistan is $99.3 \%$, and in the rest of Central Asian economies is $100 \%$. Yet, according to the national statistics, $10 \%$ of the rural population have no access to electricity [85]. Furthermore, an estimated 2 million households in Kyrgyzstan and Tajikistan [80], but also in Uzbekistan [86], experience energy poverty. 


\subsection{Environmental Sustainability}

Expectedly, FFR economies have a high reliance on fossil fuels and higher per capita energy use (Table 4). The efficiency and productivity of energy use are the lowest in Uzbekistan and Turkmenistan. Tajikistan, Kazakhstan and Kyrgyzstan demonstrate higher energy use efficiency and productivity. In Tajikistan and Kyrgyzstan, this is likely to be influenced by the modest shares of industry in GDP (around 25\% and 30\%, respectively) and energy deficits. In Kazakhstan, the metrics have improved over time, due to technological upgrades. Turkmenistan and Uzbekistan increased the environmental load, which is measured through the $\mathrm{CO}_{2}$ damage and ratio of greenhouse gas emissions versus 1990 .

Table 4. Environmental Sustainability (Source: author, based on World Bank data).

\begin{tabular}{|c|c|c|c|c|c|}
\hline Indicators & Kazakhstan & Kyrgyzstan & Tajikistan & Turkmenistan & Uzbekistan \\
\hline $\begin{array}{l}\text { Fossil fuel energy consumption, } \\
2014, \% \text { of total }\end{array}$ & 99.17 & 75.48 & 45.98 & $\mathrm{n} / \mathrm{a}$ & 97.74 \\
\hline $\begin{array}{c}\text { Energy use, kg of oil equiv. per } \\
\text { capita, } 2014\end{array}$ & 4434.64 & 650.40 & 339.85 & 4893.41 & 1419.48 \\
\hline $\begin{array}{c}\text { Energy use (kg of oil equivalent) } \\
\text { per \$1000 GDP (constant } 2011 \\
\text { PPP), } 2014\end{array}$ & 188.01 & 204.73 & 131.71 & 341.43 & 230.21 \\
\hline $\begin{array}{l}\text { Energy intensity level of primary } \\
\text { energy, MJ/\$2011 PPP GDP, } 2015\end{array}$ & 7.92 & 8.64 & 5.01 & 13.86 & 9.99 \\
\hline $\begin{array}{c}\text { GDP per unit of energy use, } \\
\text { constant } 2011 \text { PPP \$ per kg of oil } \\
\text { equiv., } 2014\end{array}$ & 5.32 & 4.88 & 7.59 & 2.93 & 4.34 \\
\hline $\begin{array}{l}\text { GDP per unit of energy use, PPP \$ } \\
\text { per kg of oil equiv., } 2014\end{array}$ & 5.62 & 5.16 & 8.02 & 3.09 & 4.05 \\
\hline $\begin{array}{l}\text { Adjusted savings: energy } \\
\text { depletion, 2017, } \% \text { of GNI }\end{array}$ & 6.21 & 0.02 & 0.04 & 5.78 & 4.62 \\
\hline $\begin{array}{c}\text { Adjusted savings: } \mathrm{CO}_{2} \text { damage, } \\
2017, \% \text { of GNI }\end{array}$ & 5.74 & 5.27 & 2.40 & 6.20 & 6.23 \\
\hline $\begin{array}{c}\text { Total greenhouse gas emissions, } \\
2012, \% \text { vs. } 1990\end{array}$ & -1.55 & -58.55 & -29.09 & 13.33 & 4.64 \\
\hline
\end{tabular}

Note: the latest available (as of 25 March 2020) data are used.

Table 5 shows the significant environmental impact of energy sectors in FFR economies. Despite comparatively low levels, energy-related environmental burden in Kyrgyzstan and Tajikistan is likely to exacerbate, given the technical condition of the nations' generating capacities.

Table 5. Energy Sectors' Environmental Footprint (Source: author, based on World Bank data).

\begin{tabular}{cccccc}
\hline Indicators & Kazakhstan & Kyrgyzstan & Tajikistan & Turkmenistan & Uzbekistan \\
\hline $\begin{array}{c}\text { Energy related methane } \\
\text { emissions, 2008, \% of total }\end{array}$ & 57.04 & 7.45 & 13.36 & 75.53 & 59.70 \\
\hline $\begin{array}{c}\mathrm{CO}_{2} \text { emissions from electricity } \\
\text { and heat production, 2014, \% of } \\
\text { total fuel combustion }\end{array}$ & 63.27 & 25.84 & 4.29 & 35.82 & 42.45 \\
\hline
\end{tabular}

Note: the latest available data are used.

\section{Analysis of NHRE Deployment Readiness}

\subsection{Energy System Structure}

Based on the WB data, electricity consumption across Central Asia varies significantly, with the gap between the highest consumption in Kazakhstan and the lowest in Tajikistan exceeding three times. Kazakhstan and Turkmenistan surpass the world average, and Kazakhstan outstrips the average in its 
income group. All Central Asian economies have higher electricity consumption than the economies in their respective income groups, which can be explained by the Soviet-era legacy of total electrification.

Central Asian energy systems demonstrate low flexibility, as they exhibit a high reliance on one principal source (Table 6) [87].

Table 6. Total Primary Energy Supply (TPES) by source, 2016, \% (Source: author, based on IEA World Energy Balances 2018).

\begin{tabular}{cccccc}
\hline Indicators & Kazakhstan & Kyrgyz Republic & Tajikistan & Turkmenistan & Uzbekistan \\
\hline Coal & 43.25 & 23.53 & 20.15 & 0 & 4.11 \\
Oil & 20.21 & 44.54 & 32.05 & 23.35 & 6.34 \\
Gas & 35.14 & 6.21 & 0.10 & 76.61 & 86.85 \\
Hydro & 1.22 & 25.70 & 47.70 & 0 & 2.70 \\
Biofuels and waste & 0.13 & 0.03 & 0 & 0.04 & 0.01 \\
Geothermal, solar, etc. & 0.04 & 0 & 0 & 0 & 0 \\
\hline
\end{tabular}

Kazakhstan primarily uses its most abundant energy resource-coal (Tables 6 and 7), which is not sustainable environmentally. The second principal energy source-gas, is not so plentiful, besides it is important for maintaining Kazakhstan's oil production as well as expansion of export $[44,88]$. Kyrgyzstan relies heavily on imported oil, which is not a sustainable option for a low-income economy. Tajikistan relies mostly on hydropower, which is in line with its endowment profile. Similarly, Turkmenistan has a preference of natural gas. Uzbekistan's reliance on natural gas appears to not be sustainable in the long-run and contradicts the country's ambitions to augment gas exports. A larger role of domestically plentiful coal is not an environmentally responsible choice, especially given the fact that Uzbekistan already exceeded its 1990 emissions levels.

Table 7. Asian Countries' Energy Resource Endowment (Source: author).

\begin{tabular}{cccccc}
\hline Indicators & Kazakhstan & Kyrgyzstan & Tajikistan & Turkmenistan & Uzbekistan \\
\hline Coal, billion tonnes, bt & 31.3 & 0.9 & 3.6 & - & 3.3 \\
Reserves to production, R/P, years & 506 & & & & 458 \\
Reserves to consumption, R/C, years & 628 & & & & 444 \\
Natural gas, trillion cubic meters, tcm & 2.4 & 0.006 & 0.006 & 7.5 & 1.8 \\
Reserves to production, R/P, years & 41 & & & 317 & 21 \\
Reserves to consumption, R/C, years & 50 & & & 687 & 28 \\
Oil, billion barrels, bb & 30 & 0.04 & 0.01 & 0.6 & 0.594 \\
Reserves to production, R/P, years & 43 & & & 9 & 34 \\
Reserves to consumption, R/C, years & 238 & & & 14 & 38 \\
Hydro, megawatt, MW & 20,000 & 26,000 & 40,000 & - & 1700 \\
\hline
\end{tabular}

Note: R/P and R/C are computed based on BP 2019.

In such a context, it is reasonable to consider closely the alternative energy sources, because all nations have plentiful RE potential. Operating by available assessments (Table 8), Kazakhstan could target at larger deployment of solar photovoltaic and wind energy, Kyrgyzstan and Tajikistan-solar, Turkmenistan—solar and wind energy, and Uzbekistan could aim at exploiting the energy of the sun and biomass.

Table 8. Technical Potential for Installed Renewable Electricity Capacity in MW (Source: author, compiled based on UNDP Renewable Energy Snapshot for respective Central Asian countries).

\begin{tabular}{cccccc}
\hline Source & Kazakhstan & Kyrgyzstan & Tajikistan & Turkmenistan & Uzbekistan \\
\hline Wind & 354,000 & 1500 & 2000 & 10,000 & 1600 \\
Solar PV & $3,760,000$ & 267,000 & 195,000 & 655,000 & 593,000 \\
Biomass & 300 & 200 & 300 & not significant & 800 \\
\hline
\end{tabular}


Currently, Kazakhstan is most actively engaged in NHRE deployment (Table 9). In 2018, the country had $60 \mathrm{RE}$ projects operating, and more than 50 projected with the total capacity to reach $2353 \mathrm{MW}$ in 2020 [89].

Table 9. Deployment of RE in Kazakhstan (Source: author, based on annual reports of Kazakhstan's Ministry of Energy, http://energo.gov.kz/index.php?id=20855).

\begin{tabular}{cccccc}
\hline Parameter & $\mathbf{2 0 1 4}$ & $\mathbf{2 0 1 5}$ & $\mathbf{2 0 1 6}$ & $\mathbf{2 0 1 7}$ & $\mathbf{2 0 1 8}$ \\
\hline Installed capacity, MW, including: & 177.52 & 251.5 & 295.7 & 342.3 & 531 \\
\hline wind & 52.81 & 71.76 & 98.16 & 112.4 & 121.5 \\
\hline small-scale HPP & 119.27 & 122.3 & 139.9 & 170.8 & 200.3 \\
\hline solar & 5.04 & 57.07 & 57.3 & 58.8 & 209 \\
\hline biofuels & 0 & 0.35 & 0.35 & 0.35 & 0.35 \\
\hline output, mn kWh, including: & 578.17 & 703 & 927.9 & 1102 & 1352 \\
\hline wind & 17.4 & 131.8 & 262 & 339 & 401.9 \\
\hline small-scale HPP & 558.15 & 424.1 & 577.2 & 649.1 & 807.4 \\
\hline solar & 2.62 & 46.96 & 86.8 & 114.3 & 142.3 \\
\hline biofuels & - & 0.48 & 1.86 & 0.06 & 1.3 \\
\hline RE electricity in total output, $\%$ & 0.62 & 3.16 & 0.98 & 1.08 & 1.27 \\
\hline
\end{tabular}

Note: $\left.{ }^{*}\right)$ according to Ministry of Energy.

Kazakhstan, especially its southern regions, has high insolation: between 2200 and $3000 \mathrm{~h}$ of sunlight per year, or equivalent to $1200-1700 \mathrm{~kW} / \mathrm{m}^{2}$ annually [90]. This makes both concentrated solar thermal and solar photovoltaic solar power generation suitable technically and feasible economically. In 2019, in cooperation with the EBRD's and European companies, Kazakhstan accomplished 100 MW a solar power station, which is the largest in Central Asia. Additionally, Kazakhstan possesses an exceptionally large potential for wind generation $[27,28]$. Geographically, the Dzungarian Gates, Mangystau Region, the Karatau Peak and the Chu-Ili Mountains are the most suitable locations for wind power [91]. Currently, Kazakhstan utilizes only a small portion of this potential having 14 wind farms (Yerementau in Akmola oblast' and Kordai in Zhambyl oblast', among others) of the total installed capacity of 180 MW (as of 2019). Despite the significant role of agriculture in the Kazakhstani economy, only $10 \%$ of the agricultural residual is used [92]. The only large-scale facility Vostok Biogas operates in the Kostanai region.

\subsection{Regulation and Political Commitment}

Readily available scores on RE policy characterize Central Asian countries progress in setting up regulatory environment for RE development (Table 10). The only country in the region with all the elements of RE policy introduced, Kazakhstan has the highest ranking. Turkmenistan has not addressed the key policy areas (such as legal framework), with other aspects suffering noticeable flaws. The rest of the group are in same ranking range. Uzbekistan has been actively developing RE regulation, which resulted in a noteworthy ranking improvement.

A more detailed overview of regulatory provisions for NHRE deployment in Central Asian countries is presented in Shadrina [83]. Arranged in a comparative format, Appendix B helps clarify the principal components of the countries' approaches. 
Table 10. Renewables (RE) Policy Scores, 2017 (Source: author, based on Renewable Indicators for Sustainable Energy, World Bank, http://rise.worldbank.org/).

\begin{tabular}{cccccc}
\hline Indicators & Kazakhstan & Kyrgyzstan & Tajikistan & Turkmenistan & Uzbekistan \\
\hline Legal framework for RE & 100 & 100 & 100 & 0 & 100 \\
\hline Planning for RE expansion & 40 & 5 & 35 & 3 & 49 \\
\hline $\begin{array}{c}\text { Incentives and regulatory support for RE } \\
\text { Attributes of financial and regulatory } \\
\text { incentives }\end{array}$ & 35 & 19 & 38 & 0 & 38 \\
\hline $\begin{array}{c}\text { Network connection and use } \\
\text { Counterparty risk }\end{array}$ & 48 & 33 & 32 & 27 & 26 \\
\hline Carbon Pricing and Monitoring & 64 & 38 & 30 & 17 & 6 \\
\hline Overall score 2017 (2010) & $60(44)$ & $32(22)$ & $36(29)$ & $8(3)$ & 30 \\
\hline
\end{tabular}

Kazakhstan endorsed long-term development strategies Kazakhstan-2050 and Concept for the Transition towards a Green Economy (which formulates the goals for 2020, 2030 and 2050). These documents state the quantitative objectives with a focus on growth and economic diversification away from the reliance on the extractive industries. Such ideas, however, are not adequately translated into actions. A significant gap exists between official goals and efforts made to achieve them. That is, the concept's goal to increase the share of wind and solar in electricity generation to $3 \%$ by 2020 has not been met. Similarly, the concept's goal of decreasing $\mathrm{CO}_{2}$ emissions in the energy sector to 2012 levels by 2020 has also not been fulfilled. Already, in 2016, $\mathrm{CO}_{2}$ emissions were $10 \%$ higher than the 2012 level, and no downward trend has set in since then.

Kyrgyzstan adopted numerous documents, "but the lack of a clearly defined hierarchy of documents, budget for the objectives and responsibility for implementation make it difficult to identify the government's key development objectives" [16]. For instance, the National Development Strategy to 2040 mentions that renewable energy will occupy $50 \%$ in the country's energy mix by 2040. However, Kyrgyzstan has no such projects (except for a few in the hydropower segment) planned. Despite the adoption of long-term programs, the efficacy of the National Development Strategy to 2040 and Strategy for Sustainable Development to 2040 is highly questionable. Neither of the two sets out measurable goals, identifies the responsible governmental agencies, provides a clear division of functions among the stakeholders and allocates the implementation budgets. Moreover, the Green Economy Concept has no associated timeline and its objectives do not specify delivery dates. Kyrgyzstan's existing strategies do not address environmental agenda. In 2019, the country was the last in Central Asia to ratify the Paris Agreement, but it did not yet adopt a long-term low-emission development strategy. Long-term objectives and numerical targets for emissions reduction and climate-change resilience are not integrated into Kyrgyzstan's strategies.

Tajikistan adopted a large number of program documents. However, there are incontinences between the goals and priorities set in various program documents. For example, the National Development Strategy to 2030 (2016) criticizes the weak diversification of energy resources and the absence of NHRE in the country's energy mix. The Program for Development in Mid-Term Perspective 2016-2020 (2016) also points out the underdeveloped energy infrastructure, lack of access to electric power in remote areas and jeopardized energy security, and emphasizes the importance of energy sources diversification with a larger role to play by solar, wind, biomass and biogas. However, the Power Sector Development Master Plan (2017) is devoted entirely to the hydropower sector, stating in passing that wind, solar, geothermal and biomass energy do not deserve consideration as the priority areas. Another example is that, despite several overlapping goals, the National Development Strategy to 2030 does not refer to the Sustainable Development Transition Concept to 2022. Strictly speaking, the latter does not present an adequate vision for the nation's sustainable development. The most obvious reason is that the document was endorsed in 2007, when the 
overall awareness of sustainability was sufficiently lower. Yet, this also shows that the regulatory environment Tajikistan's suffers from the discrepancy between all kinds of documents (master plan, program, strategy) in both time-horizon and target-setting dimensions of hierarchy. Strained financially, Tajikistan has not been sufficiently selective in its approach to foreign investments. OECD (2019) notes that Tajikistan mostly endorses projects without screening them against the national developmental and environmental goals, and without intermediate and final evaluations of approved investment projects. Another clearly identifiable aspect of officially endorsed program documents in Russian language is their poor linguistic quality.

Turkmenistan has adopted several strategic documents, such as the National Socioeconomic Development Program for 2011-2030 (2010), which has since been supplemented with a shorter-term document for 2019-2025. While these documents present Turkmenistan's vision to diversify away from its reliance on natural gas, they do not offer a concrete set of intermediate steps. Turkmenistan's strategic documents can be assessed as the least actionable; they "do not specify which state body takes ultimate responsibility for the delivery of goals, and there are no quantitative-or at least verifiable-goals against which to measure progress on implementation" [16] (p. 222).

Uzbekistan has adopted the Action Strategy on Five Priority Directions for the Development 2017-2021. In addition, every year the government publishes a government program contributing to the five policy directions: governance, rule of law, economic liberalization and development, social reforms, and security. However, some of the policy goals are not the useful benchmarks. For example, the index selected for infrastructure is linked to the Global Competitiveness Index, which has never ranked Uzbekistan, and therefore cannot serve as a mark against which to compare. Additionally, while the Action Strategy outlines a vision for the nation's development throughout 2021, Uzbekistan has not yet formally adopted a longer-term development strategy. Similarly, the strategy for RE development, drafted in 2019, has not been adopted yet. On the other hand, Uzbekistan applies innovative approaches to institution- and capacity-building. One of interesting experiences is Buyuk Kelajak, a non-governmental organization created in 2018. Connecting 240 expatriates from over 30 countries, this Expert Council developed Development Strategy Framework of the Republic of Uzbekistan until 2035. Although the government does not formally recognise the Strategy 2035 objectives, the Buyuk Kelajak initiative includes the agenda for RE and sustainable development.

Even though Central Asian countries submitted their Intended Nationally Determined Contribution (INDC) towards the achievement of the global goal of the UN Framework Convention on Climate Change (UNFCCC) in 2015 (Uzbekistan did so in 2017), they do not seem to be particularly concerned about environmental sustainability. Because of protracted economic decline in the 1990s, the Central Asian countries still have emissions growth "reserve" against 1990 (Kazakhstan and Tajikistan), and even against 2010 (Kyrgyzstan, Turkmenistan and Uzbekistan). Yet, by joining the UNFCCC and setting the INDC, more developed economies in the region Kazakhstan, Turkmenistan and Uzbekistan articulate that they share and support globally pursued ideas of sustainability. It appears that Kyrgyzstan's and Tajikistan's motivations are more pragmatically driven, because, as was pointed out in the literature review, the external financing, including aid, is increasingly linked to the sustainability agenda.

\subsection{Institutions and Governance}

Analysis in this section incorporates such rankings as the ease of doing business ranking (EDBR), corruption perception ranking (CPR) and global competitiveness ranking (CR) (Table 11). Out of 190 countries covered by the EDBR, Kazakhstan is leading in the group and progressively improving its position. Kazakhstan's strongest achievements are "enforcing contracts" (4th) and "protecting minority investors" (7th). The weakest positions are "trading across borders" (105th) and "getting electricity" (67th). Here, too, Uzbekistan most significantly improved its ranking, with the best position being "starting business" (8th) and the worst "trading across borders" (152nd). Kyrgyzstan keeps falling in the ranking since 2016, when it held the 67th position versus the 80th most recently. Its best 
performance is in "registering property rights" (7th) and the poorest in "getting electricity" (143rd). Tajikistan gradually moves up, yet in the lower part of the ranking (106th). Ease of "getting credit" is Tajikistan's strongest point (11th), while "getting electricity" is the weakest (163rd).

Table 11. Selected Rankings for the Quality of Institutional Environment in Central Asian Economies (Source: author, based on Ease of Doing Business, http://www.doingbusiness.org; Corruption Perception Ranking, https://www.transparency.org; Global Competitiveness Ranking http://reports.weforum.org).

\begin{tabular}{cccccccccccccc}
\hline & \multicolumn{4}{c}{ Ease of doing Business Rate (EDBR) } & \multicolumn{3}{c}{ Corruption Perception Rate (CPR) } & \multicolumn{3}{c}{$\begin{array}{c}\text { Global Competitiveness } \\
\text { Ranking (CR) }\end{array}$} \\
\hline Years & $\begin{array}{c}\text { Kazak } \\
\text { hstan }\end{array}$ & $\begin{array}{c}\text { Kyrgy } \\
\text { zstan }\end{array}$ & $\begin{array}{c}\text { Tajik } \\
\text { istan }\end{array}$ & $\begin{array}{c}\text { Uzbek } \\
\text { istan }\end{array}$ & $\begin{array}{c}\text { Kazak } \\
\text { hstan }\end{array}$ & $\begin{array}{c}\text { Kyrgy } \\
\text { zstan }\end{array}$ & $\begin{array}{c}\text { Tajik } \\
\text { istan }\end{array}$ & $\begin{array}{c}\text { Turkmen } \\
\text { istan }\end{array}$ & $\begin{array}{c}\text { Uzbek } \\
\text { istan }\end{array}$ & $\begin{array}{c}\text { Kazak } \\
\text { hstan }\end{array}$ & $\begin{array}{c}\text { Kyrgy } \\
\text { zstan }\end{array}$ & $\begin{array}{c}\text { Tajik } \\
\text { istan }\end{array}$ \\
\hline Latest * & 25 & 80 & 106 & 69 & 124 & 132 & 152 & 161 & 158 & 55 & 96 & 104 \\
2015 & 77 & 102 & 130 & 82 & 123 & 123 & 154 & 154 & 153 & 50 & 108 & 91 \\
2010 & 63 & 41 & 152 & 164 & 105 & 164 & 151 & 172 & 172 & 67 & 123 \\
\hline
\end{tabular}

Corruption seems to be a growing problem in all countries in the region. Even the early leader, Kyrgyzstan has somewhat retreated from its anti-corruption course.

Kazakhstan's principal components of competitiveness are "labour market", "business dynamism" and "ICT adoption", while most negative effects are generated by mediocre performance of "financial system" and nation's "health". Kyrgyzstan's overall modest competitiveness is especially affected by its weaknesses in "innovation capability", "market size", "product market" and "financial system". Tajikistan has low metrics on all the pillars of competitiveness, but especially problematic are "market size", "ICT adoption", "innovation capability", "financial system" and "business dynamism". While Turkmenistan and Uzbekistan are not included in the CR, some relevant perspectives can be drawn from their Indices of Economic Freedom (Appendix C). The two economies experience a lack of financial and investment freedoms and problems with government integrity. Turkmenistan's economy is additionally affected by lack of labor and business freedoms, judicial efficiency and property rights protection.

Indicating the ease of access to capital, credit rating is another important characteristic of the institutional quality. Table 12 indicates that Kazakhstan is the only country in the region with investment-grade credit ratings from the top agencies. Uzbekistan has made definite progress, although it is assigned the non-investment speculative grade by S\&P and Fitch, and highly speculative by Moody's. In the regional context, Uzbekistan is ahead of Kyrgyzstan and Tajikistan. The improvement of credit rating up to investment grade is essential for lowering the borrowing costs for respective governments and better business environment in these countries.

Table 12. Central Asian Economies' Sovereign Debt Credit Ratings (Source: author based on Standard and Poor, Moody's and Fitch).

\begin{tabular}{cccc}
\hline Country & S\&P & Moody's & Fitch \\
\hline Kazakhstan & BBB-/lower medium grade & Baa3/lower medium grade & BBB/lower medium grade \\
\hline Kyrgyzstan & B-/highly speculative & B3/highly speculative & \\
\hline Tajikistan & BB-/non-investment grade & B1/highly speculative & BB-/non-investment grade \\
speculative & \begin{tabular}{c} 
speculative \\
\hline
\end{tabular}
\end{tabular}

Note: no data on Turkmenistan.

Polity IV (Project, Political Regime Characteristics and Transitions), which characterizes democratic and autocratic "patterns of authority" and regime changes, evaluates all Central Asian economies, except Kyrgyzstan, as authoritarian, with the strongest authoritarian hold marked for Uzbekistan (-9), followed by Turkmenistan (-8), Kazakhstan (-6) and Tajikistan (-3). Kyrgyzstan is evaluated as a democratic nation $(+8)$. While Polity IV is acclaimed for being one of the most unbiased indexes and 
therefore is extensively employed in modern econometric research, it is not immediately clear why Uzbekistan is perceived to be more authoritarian than Turkmenistan, or why Tajikistan is perceived to be so much less authoritarian than Kazakhstan and Uzbekistan. Additionally, Kyrgyzstan's outstanding position appears to be not so well-grounded, as the country faces similar challenges in the realm of good governance.

\subsection{Capital and Investment}

Capital and technical expertise are invaluable for NHRE diffusion. Limited access to affordable bank loans and absence of local green financing schemes, high initial investment costs and risk deter potential investors in the region. Domestic lending interest rates, for example, in Kyrgyzstan and Tajikistan, are close to $20 \%$ and $30 \%$, respectively. Lacking domestic financial resources and efficient institutions, the Central Asian countries remain dependent on external funding. Yet, even the costs of external financing are indicated as one of the factors behind low price competitiveness of RE. In Kazakhstan, $70 \%$ of RE projects are implemented with the international institutions' financing at $12-13 \%$ and $10-15$ years payback period (whereas the world's average interest rate for RE projects varies within $1.5 \%$ to $3 \%$ ). The average tariff for electricity generated at externally financed RE projects is assessed at 7 cents/kWh, while electricity from traditional sources is priced at 2 cents $/ \mathrm{kWh}$ [93].

Compared to other economies in the region, the investment climate in Kazakhstan is more attractive, which makes the country the main recipient of foreign direct investments (FDI) [16]. According to the National Bank of Kazakhstan, in 2018, the Netherlands was the largest investor (30.29\%), followed by the US (22.02\%), Switzerland (10.47\%), Russia (6.18\%) and China $(6.08 \%)$. Traditionally, the oil and gas sectors are the largest recipient of FDI (49.80\% in 2018). In Kazakhstan, NHRE projects are financed by ABB, KB Enterprises, Solarnet Investment GmbH, United Green, Nomad Solar (a Kazakhstani company co-owned by Total Eren SA of France and Access Infra Central Asia Ltd. of the UAE), to name but a few. However, a substantial role in NHRE development in Kazakhstan (and even more so in less developed economies in the region) belongs to the international financial institutions, most of all to the EBRD (who also assisted in setting the legal framework for RE), but also Asian Development Bank (ADB), Eurasian Development Bank (EDB) and the United Nations Framework Convention on Climate Change (UNFCCC)). Affiliated with Kazakhstan's sovereign wealth fund, Samruk-Kazyna Invest and Kazakhstan's national energy company Samruk Energy are often co-financing NHRE projects.

Kyrgyzstan offers some attractive regulatory elements, such as $10 \%$ profit tax. However, the government lacks the capacity for effective implementation, and the economy is afflicted with the poor quality of ageing physical infrastructure [16]. Climate change agenda becomes increasingly critical for Kyrgyzstan, as melting glaciers challenge the future of hydropower-centred energy. Close to $80 \%$ of FDI is absorbed by gold extraction and mining industries. Kyrgyzstan is at high risk of debt stress, with the gross debt equal to $94.58 \%$ of GDP (as of 2019). China is the largest investor and creditor of Kyrgyzstan. According to the Ministry of Finance, in 2018, 49\% of FDI came from China. China's Exim Bank holds $44.8 \%$ of Kyrgyzstan's external public debt. The loans under the Belt and Road Initiative (BRI) have been actively used for funding various projects in the national economy, including the energy sector. Other origins of FDI are Russia (16\%), Kazakhstan ( $8 \%)$, Germany $(5 \%)$ and the UK (5\%).

Tajikistan's strategy to attract FDI in metal extraction and energy also produced a significant risk of debt stress. The country's debt equaled $87.61 \%$ of GDP in 2019 (compared to 30\% in 2015). 80\% of the debt is held by China's Export-Import Bank. Payment defaults have led to debt settlements, including licenses for mineral extraction and even the transfer of sovereignty over disputed territory to China [16]. Like in Kyrgyzstan, investments in the energy sector in Tajikistan, are focused on hydropower. The Roghun Hydropower Plant is the pillar of the National Development Strategy of Tajikistan to 2030. Together with Kyrgyzstan, Tajikistan is engaged in the World Bank-funded Central Asia-South Asia Electricity Transmission and Trade Project (CASA-1000), which promises substantial electricity export revenues. Similar to other Central Asian economies, Tajikistan is involved in the Line D of the Central Asia-China gas pipeline. 
Turkmenistan seeks larger FDI inflows, which is critical to its energy sector. The country's largest foreign investor is China, followed by Russia [16]. Turkmenistan has relatively low gross external debt, however, the debt to GDP ratio has been rising (25.9\% in 2018). Turkmenistan does not face energy security concerns of the kinds some of the neighbors do, but its reliance on China for natural gas exports exposes the economy to a profound market risk.

Since 2017, Uzbekistan has been working towards improving the investment climate. At the institutional level, new agencies have been created under the Ministry of Investment and Foreign Trade, including the Foreign Investment Agency. The dominance of state-owned enterprises (SOEs) persists, although Uzbekistan (like Kazakhstan) promotes the public-private partnerships for RE development (a respective law was endorsed in 2019). Russia is the largest investor in Uzbekistan, contributing $55 \%$ of FDI, followed by China (15\%). Almost $50 \%$ of FDI is directed to the coal, oil and natural gas industries. In 2016, one of the most energy- and carbon-intensive countries in the world, Uzbekistan initiated the development of RE, particularly solar. With the help of NHRE, Uzbekistan aims to diversify energy mix, reduce dependence on gas and improve high-quality energy access.

Low FDI in NHRE across the region are not compensated by ODA allocations (Appendices D and E). In Central Asia, Kyrgyzstan and Tajikistan are the main recipients of aid (6.3\% and $3.7 \%$ as a ratio to GNI, respectively), although the energy sector at large, and NHRE, in particular, are not among the priority areas for ODA donors.

By comparison, China's investments in energy sectors across Central Asia were significant (Appendix F). Since 2014, all energy-linked projects are implemented under China's BRI. It is easy to notice that the largest financing was allocated to conventional energy (gas and oil), although RE projects in Kazakhstan and Uzbekistan have also been receiving Chinese capital since 2016. Overall, about $2.62 \%$ of Chinese FDI in Kazakhstan and 4.3\% in Uzbekistan were directed to RE projects.

To sum up this section, we agree with Boute [94] (p. 16), who notes that in Central Asia's downstream energy infrastructure, " ... certain foreign investments ... represent an informal constraint on energy market reform in the region ... (F)oreign investments in Central Asian energy sector are a prominent example of geopolitical investments or infrastructure diplomacy". Boute further elaborates that "... (i)t is ... difficult to find a commercial rationale to explain ... foreign energy investments in the region, particularly in Tajikistan and Kyrgyzstan, where energy market conditions cause the greatest concern", but this does not prevent the Russian and Chinese SOEs from investing, because they pursue "... geostrategic interests, as part of the home state's infrastructure diplomacy" (p. 259).

Our analysis demonstrates that Kyrgyzstan and Tajikistan are easier targets for countries pursuing various interests in Central Asia. These economies trapped in a vicious circle of unaccomplished market reforms and weak institutions have developed a dependency on externally provided resources.

\subsection{Infrastructure and Business Environment}

Central Asian electricity markets share common regulatory principles and institutional characteristics originating in the Soviet era. However, the contemporary regulatory environment diverges significantly across the Central Asian states. The business environment for NHRE development in all Central Asian economies cannot be characterized as satisfactory; albeit, positive shifts are undeniable. An important parameter, the ease of receiving electricity, varies greatly by country. Uzbekistan streamlined the procedures (Table 13) and outperformed Kazakhstan, moving closer to the best performers. In all economies except for Kazakhstan, the costs of getting access to electricity undermine the credibility of earlier discussed parameter of $100 \%$ access to electricity. It is unlikely that the entire population in low-, lower- and middle-income economies can afford electricity access, whose cost exceeds per capita income by 4 to 9 times. 
Table 13. Getting Access to Electricity (Source: Doing Business 2018. Reforming to Create Jobs. World Bank Group, 2018, pp. 170, 172, 198, 203; and Doing Business 2020. Country Profile (for each respective country); World Bank Group, 2020).

\begin{tabular}{ccccccccc}
\hline \multirow{2}{*}{ Parameter } & \multicolumn{2}{c}{ Kazakhstan } & \multicolumn{2}{c}{ Kyrgyzstan } & \multicolumn{2}{c}{ Tajikistan } & \multicolumn{2}{c}{ Uzbekistan } \\
\cline { 2 - 10 } & $\mathbf{2 0 1 8}$ & $\mathbf{2 0 2 0}$ & $\mathbf{2 0 1 8}$ & $\mathbf{2 0 2 0}$ & $\mathbf{2 0 1 8}$ & $\mathbf{2 0 2 0}$ & $\mathbf{2 0 1 8}$ & $\mathbf{2 0 2 0}$ \\
\hline $\begin{array}{c}\text { Getting electricity, rank } \\
\text { Distance to frontier score for } \\
\text { getting electricity, 0-100 }\end{array}$ & 76.77 & 81.6 & 44.19 & 58.6 & 35 & 51.1 & 85.5 & 86.9 \\
\hline Procedures, number & 7 & 6 & 7 & 7 & 9 & 9 & 4 & 4 \\
\hline Time, days & 77 & 71 & 125 & 111 & 133 & 98 & 88 & 88 \\
\hline $\begin{array}{c}\text { Cost, \% of income per capita } \\
\text { Reliability of supply index and } \\
\text { transparency of tariffs index, 0-8 }\end{array}$ & 47.4 & 35.9 & 814.4 & 683.9 & 811.5 & 867.8 & 833.1 & 441.2 \\
\hline
\end{tabular}

Comparatively, Kazakhstan has done more profound transformations consistent with the logic of RE development. "Kazakhstan has opted to organize its electricity market in a quasi-liberalized basis, whereas the other Central Asian countries largely continue to follow the command-and-control (monopoly) approach" [94] (p. 89). Kazakhstan has privatized most of its power sector except for high voltage transmission. Around $97 \%$ of power plants are privately owned. State-owned electricity companies are system operator KEGOC (a 100\% state-owned transmission and dispatch company assigned an exclusive right as a renewable energy buyer), electric power and electric capacity market operator JSC Kazakhstan Wholesale Electric Power Market (KOREM) and Samruk-Energo. The latter two are managed by the National Wealth Fund Samruk-Kazyna. 39\% of total generating capacity is operated by Samruk-Energo. There are 20 regional distributing and more than 100 transmission companies. More than 160 retail supply companies (some are state-owned) purchase electricity from generating companies or at the centralized auctions, and sell it to the retailers and final consumers [95]. Wholesale electricity prices are determined by the market, which is administered by the market operator KOREM. Consumers can choose a provider of electric power. By 2025, a member of the Eurasian Economic Union (EAEU) Kazakhstan (together with Kyrgyzstan) will be integrated into the Common Electric Power Market (CEPM) [44,45].

In Kyrgyzstan, a state-owned OAO Elektricheskie Stantsii (OJSC Electric Stations) produces 98\% of electricity and OAO NES Kyrgyzstana (OJSC National Energy Network Kyrgyzstan) dominates the transmission segment. The laws on Energy and on Electrical Power require the restructuring of both companies. Electricity generating plants of under $30 \mathrm{MW}$ capacity can be privately owned. Legally, the electricity market is unbundled, but the system operators retain distribution and supply services.

In Tajikistan, the state owns the electricity generating company Bargi Tajiks. The only private OJSC Pamir Energy operates in the Gorno-Badakhshan Autonomous Region. Both companies are monopolists, providing all spectrum of services. In 2018, the unbundling of Barki Tojik into JSC Electricity Transmission Networks and OJSC Power Distribution Networks was decided.

In Turkmenistan, the electricity market is controlled by a vertically integrated state-owned Turkmenenergo. The company owns and operates the grid, generates and distributes electricity. Turkmenistan has been known for the lowest electricity tariffs in the world, but the worsening public finance forced the government to launch unpopular tariff reforms.

In Uzbekistan, the electricity market reveals a structural similarity with the already discussed examples. The state-owned electricity company UzbekEnergo generates $97.5 \%$ of the country's electricity [96]. The remaining share is the capacity of a small HPP, in which $84 \%$ is held by state-owned Uzsuvenergo and the remainder is owned by small block-stations enterprises. In 2019, the Strategy for the Development and Further Improvement of Energy Sector endorsed the unbundling of Uzbekenergo into generation, transmission and distribution segments. The generation and distribution sectors will 
be privatised, while the transmission will remain under the control of Natsional'nye Elektricheskie Seti Uzbeksiatna.

Characterising business environment, in Kazakhstan and Uzbekistan, the governments are aiming beyond a mere application of imported RE technologies and equipment; they target the localization of RE innovations. To this end, the manufactures of equipment for RE sector are granted tax exemptions and other stimuli. Price competitiveness and equipment efficiency are yet to be attained, however the political will to support the RE niche is in place. Additionally, to support the intraregional and international cooperation for RE diffusion, expertise exchange and investments facilitation, the two nations started holding relevant events. After the Astana EXPO-2017 “Future Energy: Solutions for Tackling Humankind's Greatest Challenge", Kazakhstan launched annual Central Asian Renewable Energy Summits. In 2018, Uzbekistan held the International Environmental Forum "Strengthening Cooperation for Environment and Sustainable Development" and decided to make the Central Asia Climate Change conference an annual event. Besides, the two countries regularly organize the international forums for RE investment and financing.

Other parameters helping assess the business environment for innovation intensive RE segment are the ratio of Internet users and the "number of mobile phone units per 100 people". On the first indicator, Kazakhstan (78.9\%) and Uzbekistan (52.3\%) lead, followed by Kyrgyzstan (38\%). As far as the second metrics is concerned, Turkmenistan has the highest ratio (162.9), followed by Kazakhstan (142) and Kyrgyzstan (122.6). Surprisingly, Uzbekistan has only 75.9 units per 100 people.

\subsection{Human Capital}

Assessing human capital, we pay attention to a composite indicator called Education Index (EI), which in turn is a part of other aggregate indicator-Human Development Index. In 2018, traditionally the top in the group, Kazakhstan's EI was 0.817, Kyrgyzstan's 0.734, Uzbekistan's 0.718, Tajikistan's 0.673 , and Turkmenistan's 0.628. In 2018, share of population with educational attainment "bachelor+" was assessed at $34.1 \%$ in Kazakhstan, $16.3 \%$ in Uzbekistan and $11.9 \%$ in Tajikistan. Thus, in this area, two leaders are clearly identifiable.

\section{Discussion}

We hypothesized that more advanced, economically and institutionally, nations are more likely to engage in NHRE diffusion. On economic performance, we showed through a range of indicators the supremacy of Kazakhstan and somewhat solid standing of Turkmenistan. Albeit distant from these two by the income level, Uzbekistan is the most dynamically transforming economy in the region with massive potential. We spare more attention to explaining the second component of our argument-the institutional quality, and the role it plays in NHRE development.

Unfortunately, frequent incorporation of this category in modern socio-economic research has not made the meaning of institutional quality absolutely lucid. This study did not aim at such clarifications for a reason of space; therefore, we skip discussion about the meaning of the category per se. We support our argument about the quality of institutions in Central Asian countries with the Institutional Quality Index (IQI), which incorporates assessments of political and market institutions. When, based on the results of our analysis, we claim that the institutional quality in Kazakhstan is superior compared to that of the peers in the region, we weigh our assessment against the evidence from other sources. Thus, according to IQI 2019, institutional quality in Kazakhstan was assessed as the highest in the region (0.4652, with political institutions assessed 0.2287 , and market 0.7018$)$. Kyrgyzstan was ranked the second (0.3824, 0.2528 and 0.5120), Uzbekistan the third $(0.2280,0.0728$ and 0.3832), Tajikistan the fourth $(0.2262,0.0836$ and 0.3689$)$, and Turkmenistan earnt the lowest rank in the region $(0.0560,0.0453$ and 0.0667$)$.

One observation in relation to the quality of institutions is important. In the introduction, we characterized the EAEU's financing and Russia's investments in RE projects in Kazakhstan as a positive example. Why, then, has Russia's involvement in the energy sector in Kyrgyzstan been 
assessed as counterproductive? We offer the following explanation. Russia and Kazakhstan are often compared for a similarity of the paths of their economic transformations and institutional reforms. Over time, their economic systems (co-)evolved to yet again attain (à la post-Soviet) institutional compatibility and cohesiveness [44]. The cooperation builds upon mutually acceptable standards. To boost the attractiveness of such transactions, even higher than national benchmarks sometimes need to be followed. The case is different for Kyrgyzstan and Tajikistan, who did not implement profound transition reforms, and who, as we demonstrated, are often falling under the sway of Russia and China. To link this to the paper's argument that more advanced economically and institutionally countries are more likely to commence NHRE development, the underlying logic is that economically weaker nations develop external dependencies (Section 4.4) and stagnate being trapped by their own, as well as imported, institutional inefficiencies (Section 4).

The analysis of NHRE diffusion across Central Asia allows us to distinguish between three approaches. The first can be referred to as proactive, to reflect the nations' vision on RE diversification, their delivery of policies and their attempts to combine domestic financial and technological means with the international capacities. Two examples of such approach are Kazakhstan and Uzbekistan. The second approach can be described as reactive. The countries in focus are Kyrgyzstan and Tajikistan, who seem to retain their priorities for hydropower, signaling, at the same time, their intentions to introduce NHRE. Yet, such intentions are stated in unmeasurable form and the required regulatory mechanisms are largely missing. A clear example of such signaling is set by Kyrgyzstan, whose Green Economy Concept suggests attracting more FDI for sustainable infrastructure to meet the nation's SDGs. To some extent, the pursuance of such passive approach is understandable: the lower-income steadily growing economies with rapidly increasing population face a range of serious constraints in the energy sector, which they cannot address with their own scarce financial and technological resources. However, the reactive approach does not offer the long-term systemic solutions to the augmenting problems of these poorer economies in the region. Finally, Turkmenistan does not fit with the described approaches and deserves its own category, which we coin indifferent. Turkmenistan is a hydrocarbons abundant, relatively wealthy and utterly reclusive economy. Such set of characteristics determines the country's present energy mix with zero NHRE and explains the absence of prominent agenda for NHRE development. Yet, the indifferent approach contains potential risks, such as limited energy affordability (if energy export revenues plunge following the collapse in the commodity markets, the government will no longer be able to subsidize energy), or limited energy accessibility (the Soviet era-erected facilities will eventually crumble and the government will need to repair or construct new energy infrastructure in rural areas). Denying any decent degree of openness for the entire economy, Turkmenistan has been limiting its contacts in the energy sector to one segment-natural gas, and one partner-China; a precarious setting.

\section{Conclusions and Policy Implications}

The paper examined the case of NHRE deployment in Central Asia. It demonstrated that more advanced economically and institutionally countries in the region are more motivated to commence NHRE development. The principal findings can be summarized as follows:

- NHRE deployment in Central Asia is uneven;

- The fossil-fuel rich and more developed Central Asian economies display higher commitment to NHRE, with Turkmenistan being an outlier;

- All Central Asian economies depend on external resources-innovation and capital—for NHRE development, but only lower-income Kyrgyzstan and Tajikistan develop detrimental dependencies; and

- Institutional quality allowing economic openness and boosting learning competencies is critical for NHRE advancement. This, in our view, explains non-engagement of Turkmenistan, Kyrgyzstan and Tajikistan in NHRE deployment. 
Linking the identified approaches with policy implications, it seems to be appropriate to consider three possible formats. The first can be called "engage and cooperate", meaning that domestic and foreign partners-private, corporate or institutional—can have commercially or elsehow beneficial cooperation with the countries practicing the proactive approach to RE development. Because the motivation for NHRE development is initially in place in these countries, the domestic and foreign partners need to effectively communicate their priorities. The followers of proactive approach already act as regional anchors in the realm of NHRE development. By holding regular international symposiums and conferences, they offer platforms for productive communication among official, business and institutional stakeholders across a multifaceted agenda.

Policy recommendations corresponding to the second identified approach (reactive) can be called "learn and follow". Kyrgyzstan and Tajikistan shall realize that the sustainability agenda shall be pursued, not for hitting concrete short-term narrow goals (like getting the necessary funding), but rather for finding feasible solutions to the multifaceted problems these nations face (energy-water nexus, climate change, energy poverty, to name but a few). Given higher investment risks in these economies, the institutional investors are more likely partners, which makes policy recommendation easier to implement. To shift the dialogue to a more constructive format, the institutional investors shall apply stricter sustainability criteria when considering energy investment in such economies. After all, the educational support for forging better practices has been made available to these economies. To compete for ODA and FDI, the recipients are expected to demonstrate the adequacy of their regulatory and institutional capacities.

Policy recommendations for the third (indifferent) approach are the hardest to formulate. As the international cooperation necessitates a certain degree of economic openness and institutional compatibility, gradual progress in the regional (Central Asia-China gas pipeline) and international (TAPI gas pipeline) energy cooperation may help enhance communication among official, business and institutional actors. Again, regularly held summits for renewable energy development in Central Asia may assist greatly in diffusing knowledge, sharing the best practices and building institutional capacity.

This study is a result of meticulous work on collecting data and information, organising and analysing it. Yet, the study has a number of limitations. Some of the limitations are objective. For instance, it is impossible to apply statistical methods to the analysis of a phenomenon in its nascent form, when there is no sufficient data. Furthermore, even the traditional quantitative analysis is often problematic for the absence of data (as we have noted, this is especially the case for Turkmenistan). When this paper has been almost finalised, a dam collapse in Uzbekistan occurred to cause large damage to the agricultural regions in neighbouring Kazakhstan. In such a context, we reiterate our argument that Central Asian nations need a more vigorous engagement in NHRE diffusion. To support the nations' endeavours, interdisciplinary scholarly efforts on a wide range of topics-from purely technical (like studies of the advantages of specific RE technologies) and narrow (like RE and women's empowerment) to broader (like intra-regional cooperation in distributed energy systems)—are timely and, hopefully, will follow before long.

Funding: This research was supported by Waseda University grant-in-aid 2019R-069.

Conflicts of Interest: The author confirms that there are no known conflicts of interest associated with this publication. 


\section{Appendix A}

Table A1. Data Sources (Source: author).

\begin{tabular}{|c|c|}
\hline Indicator & Data Source \\
\hline corruption & $\begin{array}{c}\text { Transparency International Corruption Perceptions } \\
\text { Index (CPI) }\end{array}$ \\
\hline education quality & $\begin{array}{l}\text { Education Index (Component of Human } \\
\text { Development Index, HDI) }\end{array}$ \\
\hline $\begin{array}{l}\text { electrification, use of solid fuels, share of electricity from } \\
\text { renewables/coal/gas/hydro }\end{array}$ & World Bank, World Development Indicators (WDI) \\
\hline energy access and use & International Energy Agency (IEA) \\
\hline $\begin{array}{l}\text { energy efficiency regulations, renewable energy } \\
\text { regulations, energy access regulations }\end{array}$ & $\begin{array}{c}\text { World Bank, Regulatory Indicators for Sustainable } \\
\text { Energy (RISE) }\end{array}$ \\
\hline energy subsidies, externalities & International Monetary Fund (IMF) \\
\hline fossil fuel reserves, production, consumption & BP Statistical Review of World Energy (BP) \\
\hline fuel imports and exports & World Trade Organization (WTO) \\
\hline import diversity & $\begin{array}{c}\text { United Nations Conference on Trade and } \\
\text { Development (UNCTAD) }\end{array}$ \\
\hline $\begin{array}{l}\text { industry electricity price, quality of electricity supply, rule } \\
\text { of law, access to credit }\end{array}$ & World Bank, Doing Business Indicators (DBI) \\
\hline Institutional Quality Index (IQI) & Libertad y Progreso \\
\hline investment freedom & The Heritage Foundation \\
\hline nationally determined contributions (NDC) commitment & $\begin{array}{l}\text { United Nations Framework Convention on Climate } \\
\text { Change }\end{array}$ \\
\hline new renewable capacity built, low-carbon industry jobs & International Renewable Energy Agency (IRENA) \\
\hline official development assistance (ODA) & OECD Statistics, Creditor Reporting System (CRS) \\
\hline $\begin{array}{l}\text { policy stability, transportation infrastructure, availability of } \\
\text { technology, quality of education }\end{array}$ & $\begin{array}{l}\text { World Economic Forum Global Competitiveness } \\
\text { Index (GCI) }\end{array}$ \\
\hline Polity IV & Center for Systemic Peace \\
\hline
\end{tabular}




\section{Appendix B}

Table A2. Regulation and Political Commitment to RE Development in Central Asian Countries (Source: author)

\begin{tabular}{|c|c|c|c|c|c|}
\hline & Specialised Agency & Programme Document, RE Targets & RE Law & Energy Saving \& Climate-Change Policy & Membership in International Organisations \\
\hline 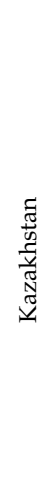 & $\begin{array}{l}\text { Green Economy } \\
\text { Council within the } \\
\text { Ministry of Energy }\end{array}$ & $\begin{array}{l}\text { - National Concept for Transition to a } \\
\text { Green Economy up to } 2050 \text { (2013): } \\
-\quad \text { alternative energy (including } \\
\text { nuclear) in electric power } \\
\text { generation to 3\% by 2020,30\% by } \\
\text { 2030, and 50\% by 2050 } \\
-\quad \text { by 2020, 106 electricity generating } \\
\text { units, capacity } 3000 \mathrm{MW}\end{array}$ & $\begin{array}{l}\text { - Law on Supporting the Use of } \\
\text { Renewable Energy Sources (2013): } \\
\text { - } \quad \text { FIT for } 15 \text { years (2013-2028) for } \\
\text { biomass, solar, wind, geothermal } \\
\text { and HPPs of up to } 35 \mathrm{MW} \\
\text { - } \\
\text { investment stimuli: subsidies } \\
\text { equivalent to up to } 30 \% \text { of the } \\
\text { costs related to land acquisition, } \\
\text { construction, and } \\
\text { equipment purchases }\end{array}$ & $\begin{array}{l}\text { - energy saving: to reduce energy } \\
\text { intensity by } 25 \% \text { by } 2020,30 \% \text { by } 2030 \text {, } \\
\text { and } 50 \% \text { by } 2050 \text { against the levels } \\
\text { of } 2008 \\
\text { - facilitation of modernization of existing } \\
\text { power generation, power grids, and oil } \\
\text { refining installations } \\
\text { endorsement of } 15 \% \text { (2030) \& } 40 \% \\
\text { (2050) reduction in greenhouse gas } \\
\text { emissions vs. } 2012 \text { level } \\
\text { policies to support the development } \\
\text { and inclusion of available RE sources in } \\
\text { the energy mix }\end{array}$ & $\begin{array}{l}\text { Paris Agreement under the United Nations } \\
\text { Framework Convention on Climate Change } \\
\text { COP } 21 \text { (ratified in 2016), IRENA, INOGATE }\end{array}$ \\
\hline
\end{tabular}

- National Energy Program of the Kyrgyz Republic for 2008-2010 and the Strategy for the Fuel-Energy Complex

Conelopt for Eng

- $\quad$ Law on RES (2008):

Coordination

- Concept for Energy Sector
Development to 2030 (2016)

Council for the - National Development Strategy to 2040
(2018): Development and

- FIT for up to 8 years to ensure the reimbursement of

- RES in energy mix $50 \%$

Legistati

$\begin{array}{ll}\text { - } & \text { RES in energy mix } 50 \% \\ \text { - } & \text { energy intensity \& }\end{array}$

energy intensity \&
efficiency-level of

OECD countries

Framework in the

Conservation and

Energy Efficiency

- Green Economy Concept:

"Kyrgyzstan-Country of Green Economy":

imported equipment and materials for RES facilities exempt from customs duties

- transmission companies to purchase RES electricity
- Strategy for Sustainable Development to 2040 (2018):

- development of infrastructure, 16 projects, $\$ 8.3 \mathrm{bn}$
INOGATE, in accession to IRENA, in the process of ratification of the Paris Agreemen under the United Nations Framework Legislative Acts in the Sphere of Renewable Energy (2019) infrastructure to meet SDGs 
Table A2. Cont.

\begin{tabular}{|c|c|c|c|c|c|}
\hline & Specialised Agency & Programme Document, RE Targets & RE Law & Energy Saving \& Climate-Change Policy & Membership in International Organisations \\
\hline 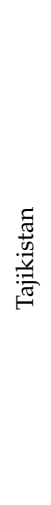 & & $\begin{array}{l}\text { - Long-term Program for Building Small } \\
\text { Hydro Power Plants for 2009-2020: } 189 \\
\text { small HPPs, 103.6 MW total capacity } \\
\text { Targeted Program for the Widespread } \\
\text { Use of RES (2007) } \\
\text { - Program for the Development of RES } \\
\text { and the Construction of Small Hydro } \\
\text { Power Plants for 2016-2020 (2015) } \\
\text { Power Sector Development Master Plan } \\
\text { (2017): } \\
-\quad \text { no room for RES }\end{array}$ & $\begin{array}{l}\text { - Law on the Use of RES (2010, } \\
\text { amendments in 2015): } \\
\text { - FIT guaranteed for up to } 15 \text { years } \\
\text { for electricity produced at wind, } \\
\text { solar, geothermal, biomass, and } \\
\text { hydro power (up to } 30 \mathrm{MW} \text { ) plants }\end{array}$ & $\begin{array}{l}\text { - Concept for Transition to Sustainable } \\
\text { Development till } 2022 \text { (2007) } \\
\text { - National Development Strategy to } 2030 \\
\text { (2016) } \\
-\quad \text { development of small-scale HPPs } \\
\text { (no concrete targets) } \\
-\quad \text { development of RE (no concrete } \\
\text { targets)) } \\
\text { - Programme for Development in } \\
\text { Mid-Term Perspective 2016-2020 } \\
\text { (2016): } \\
-\quad \text { diversification of energy sources, } \\
\text { larger role of solar, wind, biomass } \\
\text { and biogas energy }\end{array}$ & $\begin{array}{l}\text { Paris Agreement under the United Nations } \\
\text { Framework Convention on Climate Change } \\
\text { COP } 21 \text { (2017), IRENA, INOGATE }\end{array}$ \\
\hline 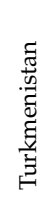 & & $\begin{array}{l}\text { drafted: } \\
\text { Concept on RE Development in the Republic } \\
\text { of Turkmenistan for 2020-2030 }\end{array}$ & $\begin{array}{l}\text { drafted: } \\
\text { the Law on Renewable Energy }\end{array}$ & $\begin{array}{l}\text { - National Strategy on Climate Change } \\
\text { (2012) } \\
\text { - the Law on Environmental } \\
\text { Assessments (2014) } \\
\text { National Programme for Energy Saving } \\
\text { for 2018-2024 (2018) }\end{array}$ & $\begin{array}{l}\text { Paris Agreement under the United Nations } \\
\text { Framework Convention on Climate Change } \\
\text { COP } 21 \text { (2016), IRENA (2019), INOGATE }\end{array}$ \\
\hline 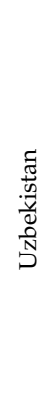 & $\begin{array}{l}\text { created Ministry of } \\
\text { Energy (2019) }\end{array}$ & $\begin{array}{l}\text { - Strategy on Five Priority Directions for } \\
\text { Development in 2017-2021 (2017): } \\
-\quad \text { RE by } 2025 \text { in electricity } \\
\text { generation } 20 \%\end{array}$ & $\begin{array}{l}\text { - Law on the Use of RES (2019): solar, } \\
\text { wind, geothermal, biomass \& HPP } \\
\text { (0.2-30 MW) \& production of } \\
\text { equipment used in RE: } \\
-\quad \text { tax exemptions for RE producers: } \\
\text { land tax (capacity 0.1 MW or } \\
\text { more) for } 10 \text { years } \\
-\quad \text { manufacturers of RE equipment: } \\
\text { exempt from all taxes for } 5 \text { years } \\
-\quad \text { property \& land tax exemption for } \\
\text { households: } 3 \text { years }\end{array}$ & $\begin{array}{l}\text { Program of Measures for Further } \\
\text { Development of Renewable Energy and } \\
\text { Improvement of Energy Efficiency in } \\
\text { the Sectors of Economy and Social } \\
\text { Sphere for 2017-2021 (2017): } \\
-\quad \text { investment requirements: } 810 \\
\text { projects, } \$ 5.3 \text { bn; } \$ 854 \text { mn private; } \\
\$ 804.6 \mathrm{mn} \text { foreign loans, } \\
\text { Uzbekistan's Reconstruction and } \\
\text { Development Fund } \$ 113.4 \mathrm{mn}\end{array}$ & $\begin{array}{l}\text { Paris Agreement under the United Nations } \\
\text { Framework Convention on Climate Change } \\
\text { COP } 21 \text { (2018), IRENA, INOGATE }\end{array}$ \\
\hline
\end{tabular}




\section{Appendix C}

Table A3. Index of Economic Freedom 2019 (Source: author, based on Heritage Foundation, https://www.heritage.org/index/explore?view=by-region-country-year).

\begin{tabular}{|c|c|c|c|c|c|c|c|c|c|c|c|c|c|c|}
\hline Country & $\begin{array}{l}\text { World } \\
\text { Rank }\end{array}$ & $\begin{array}{l}2019 \\
\text { Score }\end{array}$ & $\begin{array}{c}\text { Property } \\
\text { Rights }\end{array}$ & $\begin{array}{c}\text { Judicial } \\
\text { Effectiveness }\end{array}$ & $\begin{array}{l}\text { Government } \\
\text { Integrity }\end{array}$ & $\begin{array}{c}\text { Tax } \\
\text { Burden }\end{array}$ & $\begin{array}{l}\text { Government } \\
\text { Spending }\end{array}$ & $\begin{array}{c}\text { Fiscal } \\
\text { Health }\end{array}$ & $\begin{array}{l}\text { Business } \\
\text { Freedom }\end{array}$ & $\begin{array}{l}\text { Labour } \\
\text { Freedom }\end{array}$ & $\begin{array}{l}\text { Monetary } \\
\text { Freedom }\end{array}$ & $\begin{array}{c}\text { Trade } \\
\text { Freedom }\end{array}$ & $\begin{array}{l}\text { Investment } \\
\text { Freedom }\end{array}$ & $\begin{array}{l}\text { Financial } \\
\text { Freedom }\end{array}$ \\
\hline Kazakhstan & 59 & 65.4 & 59.3 & 56.1 & 40.3 & 93.4 & 83.7 & 41.0 & 73.9 & 86.2 & 70.9 & 80.0 & 50 & 50 \\
\hline Kyrgyzstan & 79 & 62.3 & 49.9 & 27.9 & 27.2 & 94.1 & 54.2 & 78.4 & 73.4 & 79.8 & 74.4 & 78.6 & 60 & 50 \\
\hline Tajikistan & 122 & 55.6 & 47.8 & 52.1 & 36.4 & 91.8 & 64.6 & 60.3 & 67.3 & 49.2 & 68.5 & 73.6 & 25 & 30 \\
\hline Turkmenistan & 164 & 48.4 & 31.6 & 29.8 & 20.3 & 95.9 & 92.0 & 92.3 & 30.0 & 20.0 & 73.4 & 76.0 & 10 & 10 \\
\hline Uzbekistan & 140 & 53.3 & 49.8 & 34.3 & 25.2 & 91.3 & 67.4 & 98.7 & 72.5 & 58.7 & 58.9 & 62.6 & 10 & 10 \\
\hline
\end{tabular}




\section{Appendix D}

Table A4. ODA in NHRE in Central Asian Economies, US\$ mn (Source: author, based on Creditor Reporting System, https://stats.oecd.org/Index.aspx?DataSetCode=CRS1\#).

\begin{tabular}{ccccccccccc}
\hline Year & $\mathbf{2 0 0 9}$ & $\mathbf{2 0 1 0}$ & $\mathbf{2 0 1 1}$ & $\mathbf{2 0 1 2}$ & $\mathbf{2 0 1 3}$ & $\mathbf{2 0 1 4}$ & $\mathbf{2 0 1 5}$ & $\mathbf{2 0 1 6}$ & $\mathbf{2 0 1 7}$ & $\mathbf{2 0 1 8}$ \\
\hline Kazakhstan & & 1.52 & 1.80 & & 0.02 &.. & 0.01 & 0.01 & 0.04 & 0.25 \\
Kyrgyzstan & 0.20 & 1.81 & 0.32 & & $0.36 / 14.08 *$ &.. & $-/ 0.02 *$ & 0.01 & 0.12 & 0.08 \\
Tajikistan & 0.16 & 5.57 & 1.25 & $-/ 2.03 *$ & $6.88 / 7.00 *$ & 0.05 & & 0.03 & 2.80 & \\
Turkmenistan & 0.03 & & & & & 0.04 & 0.11 & 0.02 & & \\
Uzbekistan & & & & & & & 0.23 & 0.09 & 0.09 & 0.91 \\
\hline
\end{tabular}

Note: $\left(^{*}\right)$ NHRE/RE.

\section{Appendix E}

Table A5. Share of NHRE in Total ODA, \% (Source: author, based on Creditor Reporting System, https://stats.oecd.org/Index.aspx?DataSetCode=CRS1\#).

\begin{tabular}{ccccccccccc}
\hline Year & $\mathbf{2 0 0 9}$ & $\mathbf{2 0 1 0}$ & $\mathbf{2 0 1 1}$ & $\mathbf{2 0 1 2}$ & $\mathbf{2 0 1 3}$ & $\mathbf{2 0 1 4}$ & $\mathbf{2 0 1 5}$ & $\mathbf{2 0 1 6}$ & $\mathbf{2 0 1 7}$ & $\mathbf{2 0 1 8}$ \\
\hline Kazakhstan & & 0.64 & 2.26 & & 0.03 & & 0.02 & 0.02 & 0.07 & 0.42 \\
Kyrgyzstan & 0.15 & 0.88 & 0.15 & & 0.17 & & 0.01 & 0.01 & 0.06 & 0.05 \\
Tajikistan & 0.09 & 3.94 & & & 2.87 & 0.03 & & 0.01 & 2.50 & \\
Turkmenistan & 0.23 & & & & & 0.41 & 0.78 & 0.34 & & \\
Uzbekistan & & & & & & & 0.06 & 0.03 & 0.17 & 0.33 \\
\hline
\end{tabular}

\section{Appendix F}

Table A6. China's Investments in Central Asian Economies' Energy Sectors, bn US\$. (Source: author, based on China Global Investment Tracker and https://renewablesnow.com/country/kazakhstan-569/\#, https://renewablesnow.com/news/search/?term=\&sections=all\&date=all\&country=Uzbekistan).

\begin{tabular}{|c|c|c|c|c|c|c|c|c|c|c|c|c|c|c|c|c|}
\hline Country & 2005 & 2006 & 2007 & 2008 & 2009 & 2010 & 2011 & 2012 & 2013 & 2014 & 2015 & 2016 & 2017 & 2018 & 2019 & Energy Share * \\
\hline Kazakhstan & $\begin{array}{l}4.2 \\
\mathrm{O}\end{array}$ & 1.91 & $\begin{array}{l}1.31 \\
G\end{array}$ & 0.25 & $\begin{array}{l}2.6 \\
G \\
0.94 \\
G\end{array}$ & $\begin{array}{l}0.73 \\
\mathrm{H}\end{array}$ & $\begin{array}{l}0.85 \\
\mathrm{O}\end{array}$ & $\begin{array}{l}0.15 \\
G \\
0.5 \\
G \\
0.36 \\
H \\
0.19 \\
0.9 \\
G\end{array}$ & $\begin{array}{l}5.3 \\
\mathrm{O}\end{array}$ & $\begin{array}{l}0.53 \\
\mathrm{O} \\
1.09 \\
\mathrm{O}\end{array}$ & $\begin{array}{l}0.35 \\
\mathrm{O} \\
0.12 \\
\mathrm{O}\end{array}$ & $\begin{array}{l}0.34 \\
\text { RE }\end{array}$ & & $\begin{array}{l}0.16 \\
\mathrm{RE} \\
1.5 \\
\mathrm{H}\end{array}$ & $\begin{array}{l}0.14 \\
\mathrm{RE}\end{array}$ & $\begin{array}{l}69.45 \%(24.42 / 35.16), \\
\text { oil, gas } \\
(2.62 \% \text { RE })\end{array}$ \\
\hline Kyrgyzstan & & & & & & & 0.39 & & & $\begin{array}{l}0.39 \\
\mathrm{C} \\
0.43 \\
\mathrm{O} \\
1.4 \\
\mathrm{G} \\
0.28 \\
\mathrm{O}\end{array}$ & & & & & & $\begin{array}{l}61.10 \% \\
(2.89 / 4.73), \text { gas, oil }\end{array}$ \\
\hline Turkmenistan & & & $\begin{array}{l}0.15 \\
G\end{array}$ & & $\begin{array}{l}3.13 \\
G\end{array}$ & & & $\begin{array}{l}2.92 \\
G\end{array}$ & & $\begin{array}{l}0.6 \\
G\end{array}$ & & & & & & $\begin{array}{l}100 \% \\
(6.77 / 6.8), \text { gas }\end{array}$ \\
\hline Uzbekistan & & & $\begin{array}{l}0.88 \\
G\end{array}$ & & & & & $\begin{array}{l}2.04 \\
G \\
0.23 \\
C\end{array}$ & & & & $\begin{array}{l}0.15 \\
\mathrm{RE}\end{array}$ & $\begin{array}{l}0.19 \\
G\end{array}$ & & & $\begin{array}{l}61.34 \% \\
(3.49 / 5.69), \text { gas, coal } \\
(4.30 \% \mathrm{RE})\end{array}$ \\
\hline
\end{tabular}

Notes: O-oil, G-gas, C-coal, H-hydropower, RE-renewable energy.; share of investments in energy (energy investment/ total investments); also, as specified, investments in conventional sources and RE. 


\section{References}

1. Emilio, M.F.; Lopez, M.C.; Moore, N.; Müller, N.; Hyndman, D.W. Sustainable hydropower in the 21st century. In Proceedings of the National Academy of Sciences, Washington, DC, USA, 20 November 2018; Volume 115, pp. 11891-11898. [CrossRef]

2. Tuukka, M.; Håkon, E.; Taran, N.; Thune, M.; Gonzalez, J.S. The green flings: Norwegian oil and gas industry's engagement in offshore wind power. Energy Policy 2019, 127, 269-279.

3. REN21. Renewables 2019. Global Status Report; REN21 Secretariat: Paris, France, 2019.

4. York, R.; Bell, S.E. Energy transitions or additions? Why a transition from fossil fuels requires more than the growth of renewable energy. Energy Res. Soc. Sci. 2019, 51, 40-43. [CrossRef]

5. IRENA. Renewable Power Generation Costs in 2018; International Renewable Energy Agency: Abu Dhabi, UAE, 2019.

6. Global Landscape of Renewable Energy Finance. IRENA, 2018. Available online: https://www.irena.org/-/ media/Files/IRENA/Agency/Publication/2018/Jan/IRENA_Global_landscape_RE_finance_2018.pdf (accessed on 30 May 2020).

7. IRENA. Global Energy Transformation: A Roadmap to 2050; International Renewable Energy Agency: Abu Dhabi, UAE, 2018.

8. Aklin, M.; Urpelainen, J. Renewables: The Politics of a Global Energy Transition; The MIT Press: Cambridge, MA, USA, 2018.

9. Lanshina, T.A.; Laitner, S.J.A.; Potashnikov, V.Y.; Barinova, V.A. The slow expansion of renewable energy in Russia: Competitiveness and regulative issues. Energy Policy 2018, 120, 600-609. [CrossRef]

10. Ahmadov, A.K.; van der Borg, C. Do natural resources impede renewable energy production in the EU? A mixed-methods analysis. Energy Policy 2019, 126, 361-369. [CrossRef]

11. Irandoust, M. Innovations and renewables in the Nordic countries: A panel causality approach. Technol. Soc. 2018, 54, 84-92. [CrossRef]

12. Bourceta, C. Empirical determinants of renewable energy deployment: A systematic literature review. Energy Econ. 2020, 85, 104563. [CrossRef]

13. Seriño, M.N.V. What motivates developing countries to diversify sources of renewable energy? Jpn. Asean Transdiscipl. Stud. Work. Pap. Ser. 2019, 6, 1-24.

14. SDG7: Data and Projections. International Energy Agency: Paris, France, 2019. Available online: https://www.iea.org/reports/sdg7-data-and-projections (accessed on 30 May 2020).

15. Tracking SDG7: The Energy Progress Report. International Energy Agency: Paris, France, 2020. Available online: https://www.iea.org/reports/tracking-sdg7-the-energy-progress-report-2020 (accessed on 30 May 2020).

16. OECD. Sustainable Infrastructure for Low-Carbon Development in Central Asia and the Caucasus: Hotspot Analysis and Needs Assessment, Green Finance and Investment; OECD Publishing: Paris, France, 2019. [CrossRef]

17. Bahtiyor, E.R.; Stultjes, M.G.P.; Sanaatbek, K.S.; Ruzumboy, A.E. Rogun dam-path to energy independence or security threat? Sustainability 2011,3, 1573-1592.

18. Bahtiyor, E.R.; Stultjes, M.G.P.; Ruzumboy, A.E.; Salaev, S.K. Prospects of renewable energy penetration in Uzbekistan-perception of the Khorezmian people. Renew. Sustain. Energy Rev. 2013, 21, 789-797.

19. Karimov, K.S.; Akhmedov, K.M.; Abid, M.; Petrov, G.N. Effective management of combined renewable energy resources in Tajikistan. Sci. Total Environ. 2013, 461, 835-838. [CrossRef]

20. Haris, D.; Marinakis, V.; Karakosta, C.; Psarras, J. Promoting renewables in the energy sector of Tajikistan. Renew. Energy 2012, 39, 411-418.

21. Melisande, L.F.M.; Pistorius, T. Coping with the energy crisis: Impact assessment and potentials of non-traditional renewable energy in rural Kyrgyzstan. Energy Policy 2012, 44, 130-139.

22. Babow, S.; Meisen, P. The Water-Energy Nexus in the Amu Darya River Basin: The Need for Sustainable Solutions to a Regional Problem. Global Energy Network Institute, 2012. Available online: http://www.geni.org/globalenergy/research/water-energy-nexus-amudarya-river/Water-Energy\% 20Nexus-AmuDarya-River-RD.pdf (accessed on 30 May 2020).

23. Jägerskog, A.G.J.; Lindström, A.; Björklund, G.; Bullock, A.; Löfgren, R.; de Gooijer, G.; Pettigrew, S. Regional options for addressing the water, energy and food nexus in central Asia and the Aral Sea basin. Int. J. Water Resour. Dev. 2012, 28, 419-432. 
24. Shokhrukh-Mirzo, J.; Amer, S.A.; Ward, F.A. Managing the water-energy-food nexus: Opportunities in Central Asia. J. Hydrol. 2018, 557, 407-425.

25. Laldjebaev, M.; Morreale, S.J.; Sovacool, B.K.; Kassam, K.-A.S. Rethinking energy security in practice: National vulnerability and three energy pathways in Tajikistan. Energy Policy 2018, 114, 39-50. [CrossRef]

26. Benney, T.M. Varieties of capitalism and renewable energy in emerging and developing economies. J. Econ. Policy Reform 2019. [CrossRef]

27. Karataev, M.; Clarke, M.L. A review of current energy systems and green energy potential in Kazakhstan. Renew. Sustain. Energy Rev. 2016, 55, 491-504. [CrossRef]

28. Karataev, M.; Hall, S.; Kalyuzhnova, Y.; Clarke, M.L. Renewable energy technology uptake in Kazakhstan: Policy drivers and barriers in a transitional economy. Renew. Sustain. Energy Rev. 2016, 66, 120-136. [CrossRef]

29. Jianzhong, X.; Assenova, A.; Erokhin, V. Renewable energy and sustainable development in a resource-abundant country: Challenges of wind power generation in Kazakhstan. Sustainability 2018, 10, 3315. [CrossRef]

30. Kraudzun, T. Bottom-up and top-down dynamics of the energy transformation in the eastern Pamirs of Tajikistan's Gorno Badakhshan region. Cent. Asian Surv. 2014, 33, 550-565. [CrossRef]

31. Menga, F. Building a nation through a dam: The case of Rogun in Tajikistan. Natl. Pap. 2015, 43, 479-494. [CrossRef]

32. Menga, F. Power and Water in Central Asia; Routledge: New York, NY, USA, 2018.

33. Menga, F.; Mirumachi, N. Fostering Tajik hydraulic development: Examining the role of soft power in the case of the rogun dam. Water Altern. 2016, 9, 373-388.

34. Wooden, A.E. Kyrgyzstan's dark ages: Framing and the 2010 hydroelectric revolution. Cent. Asian Surv. 2014, 33, 463-481. [CrossRef]

35. Wooden, A.E.; de la Croix, J.F.; Gullette, D. The 'great future of the country'? Dams and hydroelectricity discourses in Kyrgyzstan. In Environmental Crises in Central Asia: From Steppes to Seas, from Deserts to Glaciers; Freedman, E., Neuzil, M., Eds.; Routledge: New York, NY, USA, 2016; pp. 52-64.

36. Bahrami, A.; Teimourian, A.; Okoye, C.O.; Shiri, H. Technical and economic analysis of wind energy potential in Uzbekistan. J. Clean. Prod. 2019, 223, 801-814. [CrossRef]

37. Bahrami, A.; Teimourian, A.; Okoye, C.O.; Shiri, H. Assessing the feasibility of wind energy as a power source in Turkmenistan; a major opportunity for Central Asia's energy market. Energy 2019, 183, 415-427. [CrossRef]

38. Bahtiyor, E.; Abylkasymova, A.; Aminjonov, F.; Moldokanov, D.; Overland, I.; Vakulchuk, R. Renewable energy policies of the central Asian countries. Cent. Asia Reg. Data Rev. 2019, 16, 1-4.

39. Bahtiyor, E.; Abylkasymova, A.; Aminjonov, F.; Moldokanov, D.; Overland, I.; Vakulchuk, R. Wind Power potential of the central Asian countries. Cent. Asia Reg. Data Rev. 2019, 17, 1-7.

40. Bahtiyor, E.; Abylkasymova, A.; Aminjonov, F.; Moldokanov, D.; Overland, I.; Vakulchuk, R. Solar Power potential of the central Asian countries. Cent. Asia Reg. Data Rev. 2019, 18, 1-7.

41. Bahtiyor, E.; Abylkasymova, A.; Aminjonov, F.; Moldokanov, D.; Overland, I.; Vakulchuk, R. Hydropower potential of the central Asian countries. Cent. Asia Reg. Data Rev. 2019, 19, 1-7.

42. Birte, P.; Mulder, P. Explaining the Diffusion of Renewable Energy Technology in Developing Countries. Giga Research Programme: Socio-Economic Challenges in The Context of Globalization; German Institute of Global and Area Studies: Hamburg, Germany, 2013; Volume 217.

43. Fethi, A. Intercourse across economic growth, trade and renewable energy consumption in developing and developed countries. Renew. Sustain. Energy Rev. 2017, 69, 527-534.

44. Shadrina, E. The common gas market of the Eurasian economic union: Progress and prospects for the institutionalization. Reg. Reg. Stud. Russ. East. Eur. Cent. Asia 2018, 7, 105-137. [CrossRef]

45. Shadrina, E. Energy integration in the Eurasian economic union: A preliminary study on progress and policy implications. In Economies, Politics and Societies in the Post-Communist Countries: Thirty Years since the Fall of the Berlin Wall; Kazakevitch, G., Akimov, A., Eds.; Palgrave Macmillan: Singapore, 2020.

46. Shujie, Y.; Zhang, S.; Zhang, X. Renewable energy, carbon emission and economic growth: A revised environmental Kuznets Curve perspective. J. Clean. Prod. 2019, 235, 1338-1352. 
47. Gonzalo-Escribano, F.; Marín-Quemada, J.M.; González, E.S.M. RES and risk: Renewable energy's contribution to energy security. A portfolio-based approach. Renew. Sustain. Energy Rev. 2011, 15, 4572-4578.

48. Emmanuel, H. Do renewable energies improve energy security in the long run? Int. Econ. 2018, 156, 127-135.

49. Aitong, L.; Xua, Y.; Shiroyama, H. Solar lobby and energy transition in Japan. Energy Policy 2019, 134, 1109050.

50. Radovanović, M.; Filipović, S.; Golušin, V. Geo-economic approach to energy security measurement-principal component analysis. Renew. Sustain. Energy Rev. 2018, 82, 1691-1700. [CrossRef]

51. Månsson, A. A resource curse for renewables? Conflict and cooperation in the renewable energy sector. Energy Res. Soc. Sci. 2015, 10, 1-9. [CrossRef]

52. Fischhendler, I.; Herman, L.; Anderman, J. The geopolitics of cross-border electricity grids: The Israeli-Arab case. Energy Policy 2016, 98, 533-543. [CrossRef]

53. Marquardt, J. The politics of energy and development: Aid diversification in the Philippines. Energy Res. Soc. Sci. 2015, 10, 259-272. [CrossRef]

54. Marquardt, J.; Steinbacher, K.; Schreus, M. Driving force or forced transition? The role of development cooperation in promoting energy transitions in the Philippines and Morocco. J. Clean. Prod. 2016, 128, 22-33. [CrossRef]

55. Marquardt, J. How Power Shapes Energy Transitions in Southeast Asia: A Complex Governance Challenge; Routledge: New York, NY, USA, 2017.

56. Marquardt, J. Conceptualising power in multi-level climate governance. J. Clean. Prod. 2017, 154, 167-175. [CrossRef]

57. Marquardt, J. Central-local relations and renewable energy policy implementation in a developing country. Environ. Policy Gov. 2017, 27, 229-243. [CrossRef]

58. Kim, J.E. Sustainable energy transition in developing countries: The role of energy aid donors. Clim. Policy 2019, 19, 1-16. [CrossRef]

59. Laurence, D.L. Asian development bank's support for clean energy. Clim. Policy 2011, 11, 1350-1366.

60. Buntaine, M.T.; Pizer, W.A. Encouraging clean energy investment in developing countries: What role for aid? Clim. Policy 2015, 15, 543-564. [CrossRef]

61. Boute, A.; Zhikharev, A. Vested interests as driver of the clean energy transition: Evidence from Russia's solar energy policy. Energy Policy 2019, 133, 110910. [CrossRef]

62. Moe, E. Vested interests, energy policy and renewables in Japan, China, Norway and Denmark. In The Political Economy of Renewable Energy and Energy Security. Common Challenges and National Responses in Japan, China and Northern Europe; Moe, E., Midford, P., Eds.; Palgrave Macmillan: London, UK, 2014.

63. Brutschin, E.; Fleig, A. Innovation in the energy sector-the role of fossil fuels and developing economies. Energy Policy 2016, 97, 27-38. [CrossRef]

64. Kuzemko, C.; Lockwood, M.; Mitchell, C.; Hoggett, R. Governing for sustainable energy system change: Politics, contexts and contingency. Energy Res. Soc. Sci. 2016, 12, 96-105. [CrossRef]

65. Ronracher, H. Analysing the socio-technical transformation of energy systems. The concept of "sustainability transitions". In The Oxford Handbook of Energy and Society; Davidson, D.J., Gross, M., Eds.; Oxford University Press: Oxford, UK, 2018.

66. Neukirch, M. Transition of energy systems: Patterns of stability and change. In Handbook of Energy Governance in Europe; Knodt, M., Kemmerzell, J., Eds.; Springer: Cham, Switzerland, 2019.

67. Goldthau, A.; Westphal, K. Why the global energy transition does not mean the end of the petrostate. Glob. Policy 2019, 10, 279-283. [CrossRef]

68. Rustemova, A. Political economy of Central Asia: Initial reflections on the need for a new approach. J. Eurasian Stud. 2011, 2, 30-39. [CrossRef]

69. Andrews-Speed, P. Applying institutional theory to the low-carbon energy transition. Energy Res. Soc. Sci. 2016, 13, 216-225. [CrossRef]

70. Jehling, M.; Hitzeroth, M.; Brueckner, M. Applying institutional theory to the analysis of energy transitions: From local agency to multi-scale configurations in Australia and Germany. Energy Res. Soc. Sci. 2019, 53, 110-120. [CrossRef]

71. Auty, R.M.; Furlonge, H.I. The Rent Curse: Natural Resources, Policy Choice and Economic Development; Oxford University Press: Oxford, UK, 2019.

72. Hancke, B. Debating Varieties of Capitalism; Oxford University Press: New York, NY, USA, 2019. 
73. Ćetković, S.; Buzogány, A. Varieties of capitalism and clean energy transitions in the European Union: When renewable energy hits different economic logics. Clim. Policy 2016, 16, 642-657. [CrossRef]

74. Negro, S.O.; Alkemade, F.; Hekkert, M.P. Why does renewable energy diffuse so slowly? A review of innovation system problems. Renew. Sustain. Energy Rev. 2012, 16, 3836-3846. [CrossRef]

75. Huaping, S.; Edziah, B.K.; Sun, C.; Kwaku, A. Institutional quality, green innovation and energy efficiency. Energy Policy 2019, 135, 111002.

76. Junxia, L. Investments in the energy sector of Central Asia: Corruption risk and policy implications. Energy Policy 2019, 133, 110912. [CrossRef]

77. Fostering Effective Energy Transition. World Economic Forum, 2019. Available online: http://www3. weforum.org/docs/WEF_Fostering_Effective_Energy_Transition_2019.pdf (accessed on 30 May 2020).

78. Evaluating Renewable Energy Policy: A Review of Criteria and Indicators for Assessment. IRENA UKERC Policy Paper. IRENA, 2014. Available online: http://www.irena.org/documentdownloads/publications/ evaluating_re_policy.pdf (accessed on 30 May 2020).

79. Cherp, A.; Vinichenko, V.; Jewell, J.; Brutschin, E.; Sovacool, B. Integrating techno-economic, socio-technical and political perspectives on national energy transitions: A meta-theoretical framework. Energy Res. Soc. Sci. 2018, 37, 175-190. [CrossRef]

80. Preliminary Findings of the Gap Analysis for Central Asia. Regional Workshop on Renewable Energy in Central Asia; IRENA: Abu Dhabi, UAE, 2017.

81. Sluhi o Razvitii VIE v Kazakhstane Neskol'ko Preuvelicheny. 16 October 2017. Available online: https://lsm.kz/sluhi-o-razvitii-vie-v-kazahstane-neskol-ko-preuvelicheny-eksperty (accessed on 30 May 2020).

82. Nabiyeva, K. Energy Transition in South. East. and Eastern Europe, South. Caucasus and Central Asia: Challenges, Opportunities and Best Practices on Renewable Energy and Energy Efficiency; Friedrich-Ebert-Stiftung: Washington, DC, USA, 2018; ISBN 978-3-96250-254-6.

83. Shadrina, E. Renewable Energy in Central Asian Economies: Role in Reducing Regional Energy Insecurity; ADBI Working Paper 993; Asian Development Bank Institute: Tokyo, Japan, 2019.

84. Gidroenergeticheskie Problemy v Tsentral'noi Azii: Vzglyad iz Kazakhstana. 12 April 2016. Available online: http://stanradar.com/news/full/20425-gidroenergeticheskie-problemy-v-tsentralnoj-azii-vzgljad-izkazahstana.html (accessed on 30 May 2020).

85. Tadjikistan: Uglublennyi Obzor Energoeffektivnosti. Sekretariat Energeticheskoi Khartii. 2013. Available online: https://energycharter.org/fileadmin/DocumentsMedia/IDEER/IDEER-Tajikistan_2013_ ru.pdf (accessed on 30 May 2020).

86. Chen, A. Uzbekistan: The new face of energy poverty in Uzbekistan. In Pulse of Central Asia; Taylor \& Francis: Abingdon, UK, 2014; Volume 1.

87. Shustov, A. Uzbekistan-Tajikistan: Kto Dast Den'gi Na GES? Ritm Yevrazii. 10 April 2019. Available online: https://www.ritmeurasia.org/news--2019-04-10--uzbekistan-tadzhikistan-kto-dast-deneg-na-ges42089?fbclid=IwAR2bRIKc-LxVN202Io_vMc6BRyo8QJdMb5sv-zMpaxy48HxWEzu3JQrgjB4 (accessed on 30 May 2020).

88. Shadrina, E. Energy cooperation and Security in Central Asia: The possible synergy between hydrocarbon rich and water rich countries. In Achieving Energy Security in Asia: Diversification, Integration, and Policy Implications; Taghizadeh-Hesary, F., Yoshino, N., Chang, Y.H., Rillo, A., Eds.; World Scientific Press: Singapore, 2019.

89. Konyrova, K. Al'ternativny Veter Peremen. 9 February 2019. Available online: https://inbusiness.kz/ru/news/ alternativnyj-veter-peremen (accessed on 30 May 2020).

90. V Kazakhstane Rastyot Dolya Vozobnovlyaemyh Istochnikov Energii V Sector Energetiki. 3 April 2017. Available online: http://mk-kz.kz/articles/2017/04/03/v-kazakhstane-rastet-dolya-vozobnovlyaemykh-istochnikovenergii.html (accessed on 30 May 2020).

91. IRENA. Case Study 2013: Wind Atlas Kazakhstan; IRENA: Abu Dhabi, UAE, 2013.

92. Pala, C. Abandoned soviet farmlands could help offset global warming. Environ. Sci. Technol. 2009, 43, 685-707. [CrossRef]

93. Dorogie Tekhnologii I Vysokie Tarify. Chto Sderzhivaet Razvitie Zelyonoi Energetiki v Kazakhstane. Informbyuro. 9 July 2019. Available online: https://informburo.kz/stati/dorogie-tehnologii-i-vysokie-tarifychto-sderzhivaet-razvitie-zelenoy-energetiki-kazahstana-.html (accessed on 30 May 2020).

94. Boute, A. Energy Security Along the New Silk Road: Energy Law and Geopolitics in Central Asia; Cambridge University Press: Cambridge, UK, 2019. 
95. Aldayarov, M.; Dobozi, I.; Nikolakakis, T. Stuck in Transition: Reform Experiences and Challenges Ahead in the Kazakhstan Power Sector; World Bank: Washington, DC, USA, 2017.

96. Renewable Energy Snapshot: Uzbekistan. UNDP. Available online: http://www.undp.org/content/dam/rbec/ docs/Uzbekistan.pdf (accessed on 30 May 2020). 